This is the final peer-reviewed accepted manuscript of

AMOROSI, ALESSANDRO; BRUNO, LUIGI; CAMPO, BRUNO; MORELLI, AGNESE; ROSSI, VERONICA; SCARPONI, DANIELE; Hong, Wan; Bohacs, Kevin M.; Drexler, Tina M.: Global sea-level control on local parasequence architecture from the Holocene record of the Po Plain, Italy. MARINE AND PETROLEUM GEOLOGY, 87. 0264-8172

DOI: 10.1016/j.marpetgeo.2017.01.020

The final published version is available online at:

http://dx.doi.org/10.1016/i.marpetgeo.2017.01.020

Rights / License:

The terms and conditions for the reuse of this version of the manuscript are specified in the publishing policy. For all terms of use and more information see the publisher's website.

This item was downloaded from IRIS Università di Bologna (https://cris.unibo.it/)

When citing, please refer to the published version. 


\title{
Global sea-level control on local parasequence architecture from the Holocene record of the Po Plain, Italy
}

\author{
Alessandro Amorosi ${ }^{a}{ }^{*}$, Luigi Bruno ${ }^{a}$, Bruno Campo ${ }^{a}$, Agnese Morelli $^{\text {a }}$, Veronica Rossi ${ }^{\text {a }}$, \\ Daniele Scarponi ${ }^{a}$, Wan Hong ${ }^{b}$, Kevin M. Bohacs ${ }^{c}$, Tina M. Drexler ${ }^{c}$ \\ ${ }^{a}$ Department of Biological, Geological and Environmental Sciences, University of Bologna, Via Zamboni 67, 40126 Bologna, Italy \\ ${ }^{\mathrm{b}}$ KIGAM Korea Institute of Geoscience and Mineral Resources, 92 Gwahangro, Yuseong-gu, Daejeon Metropolitan City, South Korea \\ ${ }^{\mathrm{c}}$ ExxonMobil Upstream Research Company, 22777 Springwoods Village Parkway, Spring, TX 77389, USA
}

\section{A R T I C L E I N F O}

Keywords:

Parasequence

Sequence stratigraphy

Stacking patterns

Shoreline trajectory

Holocene

Po Plain

\section{A B S T R A C T}

Holocene deposits exhibit distinct, predictable and chronologically constrained facies patterns that are quite useful as appropriate modern analogs for interpreting the ancient record. In this study, we examined the sedimentary response of the Po Plain coastal system to short term (millennial scale) relative fluctuations of sea level through high resolution sequence stratigraphic analysis of the Holocene succession.

Meters thick parasequences form the building blocks of stratigraphic architecture. Above the Younger Dryas paleosol, a prominent stratigraphic marker that demarcates the transgressive surface, Early Holocene parasequences (\#s 13 ) record alternating periods of rapid flooding and gradual shoaling, and are stacked in a retrogradational pattern that mostly reflects stepped, post glacial eustatic rise. Conversely, Middle to Late Holocene parasequences (\#s 4 8) record a complex, pattern of coastal progradation and delta upbuilding that took place following sea level stabilization at highstand, starting at about 7 cal ky $\mathrm{BP}$. The prominent transgressive surface at the base of parasequence 1 correlates with the period of rapid, global sea level rise at the onset of the Holocene (MWP 1B), whereas flooding surfaces associated with parasequences 2 and 3 apparently reflect minor Early Holocene eustatic jumps reported in the literature. Changes in shoreline trajectory, parasequence architecture and lithofacies distribution during the following eustatic highstand had, instead, an overwhelming autogenic component, mostly driven by river avulsions, delta lobe switching, local subsidence and sediment compaction. We document a 1000 year delayed response of the coastal depositional system to marine incursion, farther inland from the maximum landward position of the shoreline. A dramatic reduction in sediment flux due to fluvial avulsion resulted in marine inundation in back barrier position, whereas coastal progradation was simultaneously taking place basinwards.

We demonstrate that the landward equivalents of marine flooding surfaces (parasequence boundaries) may be defined by brackish and freshwater fossil assemblages, and traced for tens of kilometers into the non marine realm. This makes millennial scale parasequences, whether auto or allogenic in origin, much more powerful than systems tracts for mapping detailed extents and volumes of sediment bodies.

The Holocene parasequences of the Po coastal plain, with strong age control and a detailed under standing of sea level variation, may provide insight into the driving mechanisms and predictability of successions characterized by similar depositional styles, but with poor age constraint, resulting in more robust interpretations of the ancient record.

\footnotetext{
* Corresponding author.

E-mail address: alessandro.amorosi@unibo.it (A. Amorosi).
}

\section{Introduction}

Holocene deposits beneath modern coastal plains can serve as valuable archives for deciphering the role of relative changes of sea level on facies architecture (Boyd et al., 1992; Blum and Tornqvist, 2000; Cattaneo and Steel, 2003; Blum et al., 2013). Advantages 
for this relatively short time interval record are that: (i) sea level and climatic histories are well established; (ii) a nearly continuous and tectonically undisturbed sedimentary succession is commonly available; (iii) high resolution facies interpretation is coupled to very precise chronologic control (associated error of ${ }^{14} \mathrm{C}$ ages in the range of 20-300 years); (iv) fossil assemblages are comparable to modern bioassemblages, and therefore can be used for refined facies interpretation.

Holocene successions exhibit distinct and predictable facies patterns, and their stratigraphy has been used historically for the interpretation of transgressive regressive $(\mathrm{T}-\mathrm{R})$ trends from older deltaic and coastal depositional systems (Curray and Moore, 1964; Oomkens, 1970; Frazier, 1974; Demarest and Kraft, 1987; Suter et al., 1987; Stanley and Warne, 1994). The synchronous initiation of Holocene marine deltas by decelera tion of sea level rise, 8500 to 6500 years ago, is one of the few well documented examples of worldwide coastal system response to changing sea level conditions (Stanley and Warne, 1994; Amorosi and Milli, 2001; Hori and Saito, 2007; Hijma and Cohen, 2011).

In terms of sequence stratigraphy, the Holocene $(\mathrm{T}-\mathrm{R})$ sedimentary wedges reflect a well constrained balance between ac commodation and sediment supply (see the 'A/S ratio', Muto and Steel, 1997), and are interpreted to represent the transgressive systems tract (TST) and the overlying highstand systems tract (HST) of the classic sequence stratigraphic model (Posamentier and Vail, 1988; Van Wagoner et al., 1988), or the retrogradational (R) and lower aggradational progradational degradational (APD) systems tract of the revised ExxonMobil depositional sequence model (Neal and Abreu, 2009; Abreu et al., 2010).

There is an extensive literature detailing the depositional response of Holocene coastal systems to relative fluctuations of sea level developed on millennial to sub millennial time scales (Lowrie and Hamiter, 1995; Somoza et al., 1998; Saito et al., 1998; Morton et al., 1999; Hori et al., 2002; Tanabe et al., 2003, 2006; Leorri and Cearreta, 2004; Leorri et al., 2006; Hori and Saito, 2007; Anderson and Rodriguez, 2008; Amorosi et al., 2009, 2013a; Poulter et al., 2009; Tornqvist and Hijma, 2012; Milli et al., 2016). However in most cases, stratigraphic correlations are made with relatively poor chronologic control, and the internal configuration of millennial scale sediment packages has been predominantly conceptualized (and significantly oversimplified) rather than documented. As a result, only limited information can be inferred about the factors (allogenic versus autogenic) that might have controlled facies architecture. An exception is the recent work by Tanabe et al. (2015), who delineated the Holocene stratigraphy of the Tokyo lowland with great detail. Using $>400$ radiocarbon data as a guide to stratigraphic correlation of facies associations and stacking patterns, they traced a set of isochrons that were used to reconstruct depositional history. This technique, however, is hardly suited for the ancient record, where chronologic and spatial resolution is insufficient to allow identification of coeval rock packages over such short intervals of time.

In this study, we assess the Holocene depositional history of the Po coastal plain south of the Po River (Fig. 1), based on the identification of physically traceable stratigraphic surfaces from 12

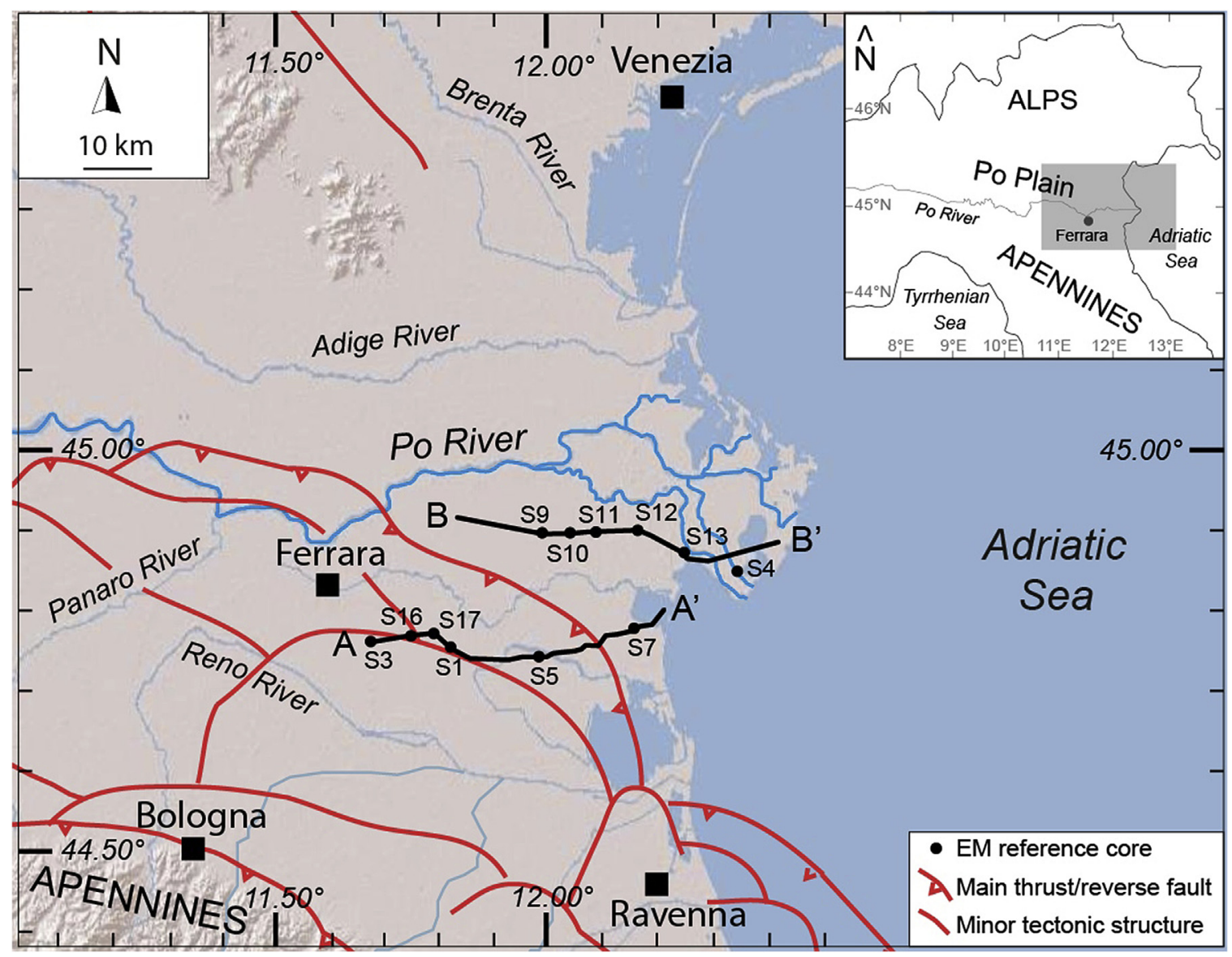

Fig. 1. Location and tectonic setting of the study area (buried thrust systems modified from Burrato et al., 2003), with indication of the two cross-sections (AA' and BB') of Fig. 3. Position of 12 'EM' reference cores is also shown. 
sediment cores, 132 radiometric dates, 740 paleontologic analyses, and 2350 borehole logs. We identified parasequences (and related bounding surfaces) as key features for stratigraphic correlation, tracing their boundaries several tens of kilometers along dip and strike. The aim of this paper is to examine parasequence development from a chronologically well constrained succession, where allogenic and autogenic signals can be deciphered and quantified. Our specific objective is to develop a conceptual framework of millennial scale stratigraphic response to relative changes of sea level that can provide insight into the interpretation and prediction of sediment/rock packages with similar stratal architecture, but for which accumulation rates and the role of all possible causative mechanisms are poorly established or unknown. A similar approach had been undertaken by Amorosi et al. (2005) and Stefani and Vincenzi (2005), but with remarkably lower facies and chronologic resolution.

Since an abundance of stratigraphic data is available only for the southern part of the Po Basin (south of Po River in Fig. 1), we selected the least deformed portion of the basin as the study area, close to the modern Po Delta (Fig. 1), in order to emphasize the role of eustatic change on stratigraphy.

\section{Geologic setting}

The Po Plain-Adriatic Sea system is part of the Alpine -Apennine and Dinarides-Hellenides foreland, an elongated basin largely filled from the Po River catchment. The external thrust front of the Apennines is buried beneath the modern alluvial plain, south of Po River, where continuous thrusting and subsi dence led to the evolution of a wedge top basin, fragmented by a set of NE verging blind thrusts and folds (Boccaletti et al., 2011 - Fig. 1). The Po Basin hosts a $>7 \mathrm{~km}$ thick sedimentary succession, Pliocene through Quaternary in age, with an upward decreasing level of tectonic deformation (Pieri and Groppi, 1981). In the Po coastal area, facies changes within the Middle Pleistocene Holocene succession follow a repetitive transgressive regressive pattern (50-100 m thick), with alternating nearshore and allu vial deposits that accumulated during interglacial and glacial periods, respectively (eccentricity driven - $100 \mathrm{ky}$ depositional cycles in Amorosi et al., 2004, 2008). In the southern Po Plain, Last Interglacial (Marine Isotope Substage 5e) deposits have been identified at depths of 100-125 m below ground surface (Amorosi et al., 2004).

As recognized by previous studies (Rizzini, 1974; Bondesan et al., 1995; Amorosi et al., 1999, 2003; 2005, 2016; Stefani and Vincenzi, 2005; Bruno et al., 2016), the Holocene succession of the Po coastal plain is a $\sim 30 \mathrm{~m}$ thick, transgressive regressive coastal wedge (TST and HST) that overlies Late Pleistocene (lowstand systems tract) alluvial deposits. The transgressive surface (Posamentier and Vail, 1988) marks the onset of a retrogradational stacking pattern of facies (Neal and Abreu, 2009). On vertical profiles, this surface is invariably marked by the abrupt shift from fluvial channel or well drained floodplain facies to poorly drained floodplain or coastal swamp deposits (Amorosi et al., 2003; Campo et al., 2017). The transgressive surface is commonly associated in core with the top of a weakly developed paleosol that formed during the Younger Dryas cold reversal, close to the Pleistocene Holocene boundary (Amorosi et al., 2016).

\section{Methods and the 'parasequence' concept}

Two stratigraphic panels, each about $50 \mathrm{~km}$ long, were oriented roughly parallel to the modern Po River and perpendicular to the present shoreline (Fig. 1). The two transects represent a linked freshwater fluvial/brackish/nearshore/shallow marine system. For each panel, we delineated the external geometry and internal architecture of parasequences.

Twelve continuous cores, $20-40 \mathrm{~m}$ in length, were drilled as part of a collaborative research project supported by ExxonMobil Upstream Research Company (Fig. 1). Core recovery was $>95 \%$. Facies analysis relied on texture, composition, physical sedimentary structures and accessory components. About 250 samples were collected for mollusk analysis, and about 490 for the analysis of the meiofauna (benthic foraminifers and ostracods). One hundred thirty two samples (wood fragments, peats, and mollusk shells) were dated using accelerator mass spectrometry (AMS), predominantly at KIGAM laboratory (Daejeon City, Korea) (Table 1 in Supplementary Material). Radiocarbon dates were calibrated with Oxcal 4.2 (Ramsey and Lee, 2013), using the Intcal13 calibration curve (Reimer et al., 2013).

For stratigraphic correlation, we used the original definition of parasequence (Van Wagoner et al., 1988, 1990), with special emphasis on the objective observation of its bounding surfaces (flooding surfaces and their equivalents), irrespective of the allogenic or autogenic processes that may have contributed to its for mation. In particular, we extend the parasequence definition into the paralic realm, to encompass surfaces across which there is evidence of abrupt increase in salinity (i.e., sharp change from brackish to marine environments, or from freshwater to brackish environments), which implies substantial facies dislocation. In the highstand shallow marine realm, parasequence boundaries correspond to clinoform boundaries. The majority of parasequences display clear shallowing upward trends. However, in this high subsidence, high sediment supply rate setting, the basal intervals of some parasequences (mostly in the TST), appear to record some deepening upward (Arnott, 1995; Zecchin and Catuneanu, 2013).

\section{Sedimentary facies}

The depositional facies that form the Holocene succession of the Po coastal plain have been illustrated at length in several papers (Amorosi et al., 1999, 2003; 2005, 2008), and will not be reiterated here. For detailed facies description, the reader is referred to these previous works. Twenty two facies associations were grouped into five broad categories, corresponding to transgressive (barrier lagoon estuary) or highstand (delta/strandplain) depositional systems (Fig. 2). Individual facies associations were differentiated on the basis of sedimentological and fossil features, reflecting changes in depth, salinity, degree of confinement, substrate, and oxygen or food availability (Scarponi and Kowalewski, 2004; Rossi and Vaiani, 2008; Amorosi et al., 2014b; Scarponi et al., 2014; Wittmer et al., 2014; Mazzini et al., 2017). Comparison with spatial distribution patterns of the modern meiofauna and mollusks allowed a robust and detailed environmental interpretation of fossil assemblages. The diagnostic lithologic, sedimentological and paleontological features for facies identification are summarized in Fig. 2. Each group is briefly described from updip to downdip locations.

\subsection{Alluvial Plain deposits}

Alluvial plain deposits include three major facies associations (Fig. 2). The fluvial channel fill facies consists of $>2 \mathrm{~m}$ thick cross stratified medium to coarse sand bodies, with erosional lower boundaries and general fining upwards (FU) of grain size. Channel fill related facies include crevasse and levee deposits, i.e. thin sand bodies and sand silt alternations containing roots, respectively. Well drained floodplain deposits are made up of variegated silt and clay, with abundant pedogenic features (Inceptisols). Pocket penetration (PP) tests record values generally $>2 \mathrm{~kg} / \mathrm{cm}^{2}$.

The meiofauna is commonly absent. Occasionally, poorly 


\begin{tabular}{|c|c|c|c|c|}
\hline Depositional System & Facies Association & $\begin{array}{c}\text { Lithology } \\
\text { Sedimentary structures }\end{array}$ & Meiofauna & Mollusks \\
\hline \multirow{3}{*}{ Alluvial plain } & Fluvial channel & $\begin{array}{c}\text { coarse to medium sand, FU trend, } \\
\text { high-angle cross-lamination, } 2 \text { - } 30 \mathrm{~m} \text { thick }\end{array}$ & \multirow{2}{*}{$\begin{array}{l}\text { commonly barren, local fragments of freshwater } \\
\text { ostracods (Candona and Ilyocypris genera) } \\
\text { and poorly-preserved marine foraminifers }\end{array}$} & \multirow{2}{*}{$\begin{array}{l}\text { mostly barren, local fragments/specimens of Pisidium } \\
\text { spp. and Valvata spp. along with opercula } \\
\text { of Bithynia cf. tentaculata (Linné, 1868) }\end{array}$} \\
\hline & Crevasse/levee & $\begin{array}{c}\text { alternating sand and silt,parallel lamination, } \\
\text { climbing ripples, } 0,5-3 \mathrm{~m} \text { thick }\end{array}$ & & \\
\hline & Floodplain & $\begin{array}{c}\text { clay and silty clay, bioturbation, root traces, } \\
\text { mottling, paleosols, } 1-20 \mathrm{~m} \text { thick }\end{array}$ & $\begin{array}{l}\text { commonly barren, at places fragments of } \\
\text { freshwater ostracods (Candona and Ilyocypris genera) }\end{array}$ & $\begin{array}{l}\text { commonly barren, local fragments/specimens of } \\
\text { pulmonate gastropods (e.g.,Cernuella spp.) }\end{array}$ \\
\hline \multirow{5}{*}{$\begin{array}{l}\text { Inner estuary (TST) and } \\
\text { Upper delta plain (HST) }\end{array}$} & Bay-head delta & $\begin{array}{l}\text { medium to fine sand, high-angle cross- } \\
\text { lamination, plant debris, } 2-5 \mathrm{~m} \text { thick }\end{array}$ & $\begin{array}{l}\text { poorly-preserved Cyprideis torosa (Jones, 1850) } \\
\text { and freshwater ostracods (e.g., llyocypris spp.) }\end{array}$ & Cerastoderma glaucum Poiret, 1789, Hydrobiidae \\
\hline & Distributary channel & $\begin{array}{l}\text { medium to fine sand, Fu trend, high-angle } \\
\text { cross-lamination, } 2-8 \mathrm{~m} \text { thick }\end{array}$ & \multirow{2}{*}{$\begin{array}{l}\text { commonly barren, local fragments of freshwater } \\
\text { to low brackish ostracods } \\
\text { (Candona and Pseudocandona genera) }\end{array}$} & \multirow{2}{*}{$\begin{array}{l}\text { mostly barren, local fragments/specimens of } \\
\text { Pisidium spp. and Valvata spp. along with opercula } \\
\text { of Bithynia cf. tentaculata (L., 1868) }\end{array}$} \\
\hline & Crevasse/levee & \begin{tabular}{|l|} 
alternating silty sand, silt and clay, parallel \\
lamination, climbing ripples, $0.5-2 \mathrm{~m}$ thick
\end{tabular} & & \\
\hline & Poorly drained floodplain & $\begin{array}{l}\text { organic-matter-rich clay, roots, plant } \\
\text { remains, } 1-5 \mathrm{~m} \text { thick }\end{array}$ & $\begin{array}{l}\text { commonly barren, locally few freshwater to low } \\
\text { brackish ostracods (Candona spp., Pseudocandona spp.) }\end{array}$ & $\begin{array}{l}\text { Anisus leucostoma (Millet, 1813), Succinella oblonga } \\
\text { (Draparnaud, 1801), Valvata macrostoma (M., 1868) }\end{array}$ \\
\hline & Swamp & $\begin{array}{l}\text { Soft clay, plant debris, wood fragments, } \\
\text { peat, parallel lamination, 1-20 m thick }\end{array}$ & $\begin{array}{l}\text { freshwater to low brackish ostracods: Pseudocandona } \\
\text { albicans (Brady, 1868), Candona neglecta (Sars, 1887) }\end{array}$ & $\begin{array}{l}\text { Bithynia tentaculata (L., 1868), Succinea putris } \\
\text { (Draparnaud, 1801), Valvata macrostoma (Mörch, 1868) }\end{array}$ \\
\hline \multirow{4}{*}{$\begin{array}{l}\text { Outer estuary (TST) and } \\
\text { Lower delta plain (HST) }\end{array}$} & Salt marsh & $\begin{array}{l}\text { organic-matter-rich clay, bioturbation, } \\
1-2 \mathrm{~m} \text { thick }\end{array}$ & \begin{tabular}{|c|} 
dominant Trochammina inflata (Montagu, 1803) with \\
euryhaline Ammonia tepida (Cushman,1926). No ostracods \\
\end{tabular} & \multirow{3}{*}{$\begin{array}{c}\text { Abra segmentum (Récluz, 1843), Cerastoderma } \\
\text { glaucum (P., 1789), Loripes orbiculatus (Millet, 1813), } \\
\text { Ecrobia ventrosa (Montagu, 1803) }\end{array}$} \\
\hline & Mud flat & $\begin{array}{l}\text { organic-matter-rich clay, bioturbation, } \\
1-2 \mathrm{~m} \text { thick }\end{array}$ & \begin{tabular}{|} 
euryhaline, high-confinement foraminifers (A. tepida, \\
Haynesina germanica-Ehrenberg, 1840). Ostracods absent \\
\end{tabular} & \\
\hline & Central lagoon/bay & bioturbated clay, 1-3 m thick & $\begin{array}{l}\text { dominant A. tepida and C. torosa. Few secondary species } \\
\text { (e.g., H. germanica and Loxoconcha elliptica-Brady, 1868) }\end{array}$ & \\
\hline & Outer lagoon/bay & $\begin{array}{c}\text { bioturbated clay-sand alternation, } \\
1-8 \mathrm{~m} \text { thick }\end{array}$ & $\begin{array}{l}\text { mixed euryhaline (A. tepid } a \text { and } C \text {. toros } a \text { ) and brackish- } \\
\text { marine species (e.g., Leptocythere and Miliolid species) }\end{array}$ & $\begin{array}{l}\text { Cerastoderma glaucum (P., 1789), Loripes orbiculatus } \\
\text { (Millet, 1813), Lentidium mediterraneum (O.G.C., 1830) }\end{array}$ \\
\hline \multirow{5}{*}{$\begin{array}{c}\text { Transgressive } \\
\text { barrier island (TST) and } \\
\text { Strandplain/Delta front (HST) }\end{array}$} & Washover & $\begin{array}{l}\text { medium to fine sand, high-angle cross- } \\
\text { lamination, } 0.5-1 \mathrm{~m} \text { thick }\end{array}$ & $\begin{array}{l}\text { poorly-preserved euryhaline (mainly C. torosa) and } \\
\text { shallow-marine taxa (e.g., Ammonia and Elphidium spp.) }\end{array}$ & $\begin{array}{c}\text { mixed mollusk assemblage of nearshore } \\
\text { and brackish taxa }\end{array}$ \\
\hline & Transgressive sand sheet & fine sand to silty sand, $0.3-2 \mathrm{~m}$ thick & \begin{tabular}{|l|} 
few commonly abraded A. beccarii (Linné, 1758), Elphidium \\
crispum (Linné, 1758), Pontocythere turbida (Mueller, 1894)
\end{tabular} & $\begin{array}{l}\text { fossil-rich interval, with characteristic taphonomic } \\
\text { signature and upward increase in marine species }\end{array}$ \\
\hline & Upper shoreface/Foreshore & \begin{tabular}{|c|} 
medium to coarse sand, high-angle cross- \\
lamination, parallel lamination, $1-5 \mathrm{~m}$ thick \\
\end{tabular} & $\begin{array}{c}\text { almost absent; locally few poorly-preserved } \\
\text { specimens of Ammonia beccarii and Pontocythere turbida }\end{array}$ & $\begin{array}{l}\text { Tritia neritea (Linné, 1758), Donax semistriatus (Poli, } \\
\text { 1795) along with stranded nearshore species }\end{array}$ \\
\hline & Lower shoreface & $\begin{array}{l}\text { fine to very fine sand, wave ripples, } \\
1-5 \mathrm{~m} \text { thick }\end{array}$ & $\begin{array}{l}\text { infralittoral fauna, dominated by sand-lover epiphytic } \\
\text { species (e.g., Carinocythereis whitei-Baird, 1850, E. crispum) }\end{array}$ & $\begin{array}{l}\text { Chamelea gallina (Linné, 1758), Acteon tornatilis } \\
\text { Linné, 1758), Atlantella distorta (Poli, 1791) }\end{array}$ \\
\hline & Mouth bar & $\begin{array}{l}\text { medium to fine sand, high-angle cross- } \\
\text { lamination, plant debris, } 3-10 \mathrm{~m} \text { thick }\end{array}$ & \multirow{2}{*}{$\begin{array}{c}\text { commonly absent, especially in mouth bar deposits. } \\
\text { Few specimens of Ammonia tepida and A. parkinsoniana } \\
\text { (d'Orbigny, 1839) and Palmoconcha turbida (Muller, 1912) }\end{array}$} & $\begin{array}{c}\text { Lentidium mediterraneum (O.G.C., 1830), } \\
\text { Donax semistriatus (P., 1795) }\end{array}$ \\
\hline \multirow{5}{*}{$\begin{array}{l}\text { Offshore (TST) and } \\
\text { Prodelta (HST) }\end{array}$} & Delta front transition & $\begin{array}{l}\text { fine sand-clay alternation, plant debris, } \\
\qquad 1-3 \mathrm{~m} \text { thick }\end{array}$ & & $\begin{array}{l}\text { Lembulus pella (Linné, 1767), } \\
\text { Corbula gibba (Olivi, 1792) }\end{array}$ \\
\hline & Offshore transition & fine sand-clay alternation, $0.5-2 \mathrm{~m}$ thick & $\begin{array}{l}\text { infralittoral, epiphytic species as Miliolids, Elphidium } \\
\text { species and Semicytherura incongruens (Muller, 1894) }\end{array}$ & $\begin{array}{l}\text { Chamelea gallina (L., 1758), Antalis inaequicostata } \\
\text { (Dautzenberg, 1891) }\end{array}$ \\
\hline & Offshore & bioturbated clay, $0.5-2 \mathrm{~m}$ thick & $\begin{array}{l}\text { several open-marine, epiphytic taxa (Miliolids, Textularia, } \\
\text { Pterygocythereis, Cytheridea neapolitana-Kollmann, 1960) }\end{array}$ & \begin{tabular}{|c|} 
Timoclea ovata (Pennant, 1777), \\
Bittium submammillatum (de Rayneval \& Ponzi, 1854)
\end{tabular} \\
\hline & Proximal prodelta & organic-matter-rich silty clay, 1-5 m thick & $\begin{array}{l}\text { dominant A. tepida-A. parkinsoniana and Palm. turbida. } \\
\text { Cribroelphidium granosum gr. and Aubignyna perlucida }\end{array}$ & $\begin{array}{c}\text { mostly barren of macrofossils, locally mollusk } \\
\text { fragments or juveniles specimens (e.g., Corbula gibba) }\end{array}$ \\
\hline & Distal prodelta & organic-matter-rich clay, 3-8 $\mathrm{m}$ thick & $\begin{array}{l}\text { dominant Nonionella turgida (Williamson, 1858), with } \\
\text { Valvulineria bradyana (Fornasini, 1900) and Bulimina } \\
\text { marginata (d'Orbigny, 1826). Rare Palmoconcha turbida }\end{array}$ & $\begin{array}{l}\text { Corbula gibba (P., 1777), } \\
\text { Turritella communis (Risso, 1826) }\end{array}$ \\
\hline
\end{tabular}

Fig. 2. Summary lithologic, sedimentological and fossil (meiofauna/mollusks) characteristics of the 22 facies associations examined in this work, and their grouping into five depositional systems. Colors are the same as in Fig. 3. (For interpretation of the references to colour in this figure legend, the reader is referred to the web version of this article.) 
preserved specimens of marine foraminifers accompanied by fragments of freshwater ostracods occur within sandy deposits. Mollusks are generally scattered, especially in well drained flood plain facies, which are commonly barren or contain at most a few mollusk fragments and/or opercula of gastropods (e.g. Bithynia). At places, especially in channel related facies, an oligotypic mollusk association dominated by the small bivalve Pisiudium and/or the gastropod Bythinia can be found. Hydrobiids are also common in deposits from freshwater vegetated areas or channel abandonment infills.

\subsection{Inner Estuary/Upper Delta Plain deposits}

This depositional system includes a variety of freshwater/ hypohaline facies associations formed as part of inner estuary (TST) to upper delta plain (HST) environments (Fig. 2). Distributary channel fill sand bodies (and related crevasse/levee facies) are typically finer grained and more isolated than fluvial channels. These bodies are transitional to poorly drained floodplain silts and clays, which can be differentiated from their well drained counterpart by their homogeneous gray color, rare Inceptisols, locally high proportion of organic matter, and remarkably lower $\left(1.2-1.8 \mathrm{~kg} / \mathrm{cm}^{2}\right)$ PP values. Swamp deposits are generally recognized by the dark gray to black color, abundant peat layers, very low $\left(<1 \mathrm{~kg} / \mathrm{cm}^{2}\right)$ PP values and high proportion of organic matter, wood fragments, and associated histosols. At channel mouths, sands are amalgamated to form bay head deltas.

Within mud dominated deposits, a scarce (poorly drained floodplain) to abundant (swamp) freshwater low brackish ostracod fauna is observed (Fig. 2). Mollusks are sparse, but diagnostic taxa are present (key species in Fig. 2). Sand bodies are commonly barren, with the exception of bay head delta sands, which show a mixture of poorly preserved, brackish species (e.g., the ostracod Cyprideis torosa, and the thin shelled bivalve Cerastoderma) and freshwater species (Ilyocypris spp., and hydrobiids; Fig. 2).

\subsection{Outer Estuary/Lower Delta Plain deposits}

Freshwater/hypohaline deposits transform seawards to a wide range of facies typical of brackish environments behind a barrier complex, as part of outer estuary (TST) or lower delta plain (HST) depositional systems (Fig. 2). The typical facies consists of a homogeneous succession of gray clays and silt (central lagoon/bay). Sand intercalations increase in frequency and thickness toward the outer lagoon/bay, whereas the clay size content increases landwards, in mud flat and salt marsh facies.

This depositional system is dominated by a brackish fauna able to tolerate changes in salinity and organic matter content. In subtidal deposits, the oligotypic meiofauna is dominated by euryhaline species (C. torosa and A. tepida) in central lagoon/bay clays, whereas a more diversified, mixed euryhaline and brackish marine meiofauna characterizes outer lagoon/bay deposits (Fig. 2). Intermittently exposed intertidal facies are barren in ostracods. The meiofauna is composed exclusively of agglutinated (salt marsh) and/or hyaline, high confinement (mud flat) foraminifers (Fig. 2). In general, mollusks comprise low diversity assemblages: the more confined (e.g., salt marsh) brackish deposits are characterized by abundant Abra segmentum, hydrobiids, and/or thin shelled Cera stoderma, whereas in less confined (outer lagoon/bay) deposits, Loripes orbiculatus, thick shelled Cerastoderma and Lentidium mediterraneum also are relatively abundant.

\subsection{Transgressive Barrier Island/Strandplain/Delta Front deposits}

This deposit is made up predominantly of well sorted, fine to medium sandy facies that accumulated in nearshore environments in response to back stepping transgressive barrier shorelines (TST) or prograding deltas and shorelines (HST Fig. 2). Transgressive deposits include lower shoreface very fine sands, sand silt alter nations (marking the offshore transition), washover sands (in back barrier position), and the transgressive sand sheet (a thin, shell rich stratigraphic interval with strong evidence of reworking by coastal processes during shoreface retreat). Highstand nearshore deposits include characteristic upward coarsening and shallowing packages of littoral (shoreface foreshore backshore) or delta front (mouth bar) sands.

The mollusk fossil content allows refined characterization of distinct facies associations. Foreshore to upper shoreface deposits show low equitability associations: the key taxon is the genus Donax, which includes fast burrowing species that prefer intertidal and upper shoreface settings. In river influenced (mouth bar) set tings, oligotypic but extremely abundant assemblages of Lentidium mediterraneum occur: this small bivalve, with $>10^{3}$ specimens retrieved per sample, is the most abundant species of the Holocene succession (Kowalewski et al., 2015). Lower shoreface facies are characterized by more diverse molluscan associations (selected key species are reported in Fig. 2). Transgressive sheet sands and other lithosomes made up of reworked sediments (e.g., washover deposits) are also distinctive, as they contain high diversity associations (see Scarponi and Kowalewski, 2007), due to the mixture of nearshore species, with up section increase in marine taxa.

A relatively highly diverse assemblage, including species that prefer vegetated sandy bottoms, typifies the meiofauna in lower shoreface facies, whereas few large sized abraded shells (Ammonia beccarii and Elphidium crispum; Fig. 2) are commonly found in the transgressive sand sheet. No foraminifers or ostracods are preserved in upper shoreface foreshore and deltaic (mouth bar) sands, likely due to high energy, harsh conditions. In contrast, a mixed assemblage of shallow marine and brackish euryhaline species characterizes washover deposits (Fig. 2).

\subsection{Offshore/Prodelta deposits}

This is the most seaward portion of the Po Plain system, relatively deeper and muddier. Transgressive shallow marine deposits (TST) consist of gray, bioturbated offshore clays and silts, whereas their highstand (HST) counterpart, prodelta muds that developed away from delta front sands, are finely laminated, with commonly abundant plant and other organic matter. Occasional thin bedded intercalations of very fine to fine sand, with sharp base and FU trend, represent storm or flood layers.

Offshore clay sized material reflects the deepest water depths attained during the entire Holocene, shown by the meiofauna assemblage that has the highest species diversity and relative abundance of open marine species (i.e., Textularia spp., Cytheridea neapolitana; Fig. 2). An infralittoral, less diversified assemblage characterizes offshore transition deposits. Key mollusk species of deep (offshore) settings include Nucula (also widespread in lower shoreface settings), Bittium submammillatum and Timoclea ovata. A significantly different assemblage characterizes prodelta muds (Breman, 1975; Jorissen, 1988; Scarponi and Angeletti, 2008)(Fig. 2). This facies association is dominated by opportunistic for aminifers, ostracods and mollusk species (i.e., Ammonia tepida A. parkinsoniana, Nonionella turgida, Palmoconcha turbida; Corbula gibba and or Turritella communis) able to tolerate stressed marine conditions, including variable salinity values and high nutrient flux and turbidity. Particular environmental conditions are recorded by the Nonionella turgida assemblage, which documents ample food availability and a limited oxygen deficiency at the sea bottom (Van der Zwaan and Jorissen, 1991), indicative of a distal prodelta or mud- 
belt setting (Fig. 2). A diagnostic trait of transgressive (sediment starved) shallow marine deposits is the widespread presence of mollusk shells with parasitic and predation scars. Conversely, highstand deposits have the highest prevalence of spionid traces (Huntley and Scarponi, 2012, 2015).

\section{Parasequence architecture}

We identified eight parasequences of Holocene age (\#s 1-8 in Fig. 3) and traced them along dip and strike across contiguous depositional systems. The lower three parasequences (\#s 1-3) occur in a retrogradational set (Fig. 3), which defines the TST (Posamentier and Vail, 1988; R systems tract of Neal and Abreu, 2009), whereas the overlying five parasequences (\#s 4-8) are aggradationally to progradationally stacked, and represent the HST (lower part of the APD systems tract of Neal and Abreu, 2009).

Parasequence 1 (11.5-9.2 cal ky BP) in the study area consists of a continuous sheet of poorly drained floodplain deposits (Fig. 3A) and swamp facies (Fig. 3B). These organic matter rich deposits are confidently correlated downdip with a partly preserved, transgressive barrier system (slightly younger than 10.5 cal ky BP), identified in the Adriatic at $42 \mathrm{~m}$ water depth (Trincardi et al., 1994; Cattaneo and Steel, 2003; Correggiari et al., 2005; Storms et al., 2008). Parasequence $2(9.2-7.7 \mathrm{cal} \mathrm{ky} \mathrm{BP})$ is characterized along dip by a genetically linked set of freshwater, brackish, nearshore and shallow marine facies, with a clear retrogradational trend. Thin (0.5-1.5 m), isolated transgressive barrier sand bodies occur in an overall backstepping pattern, and are correlated landwards to distinct bay head delta systems (Fig. 3B). Parasequence 3 (7.7-7.0 cal ky BP) documents the maximum landward migration of the shoreline, marked by a thicker $(2-4 \mathrm{~m})$, relatively well preserved, transgressive barrier complex (Fig. 3A). Updip, a large bay head delta system separates these coastal sands from brackish and freshwater facies (Fig. 3A).

A significant level of diachroneity, along both depositional strike and dip (see also Amorosi et al., 2005; Tanabe et al., 2015), is associated with the maximum flooding surface (MFS), interpreted to be at the base of parasequence $4(7.0-5.2 \mathrm{cal} \mathrm{ky} \mathrm{BP})$ : progradational and retrogradational stacking patterns are observed simultaneously in distinct parts of parasequence 4 , as documented by the seaward shift of the shoreline, as opposed to a $15 \mathrm{~km}$ landward expansion of the brackish zone in back barrier position (Fig. 3A). The coastal system in parasequence 5 (5.2-2.8 cal ky BP lower HST) is dominantly aggradational.

Parasequences 6 to 8 ( $<2.8$ cal ky BP) exhibit recurring stratal architectural patterns that, as a whole, record rapid progradation of the coastal system (upper HST). Parasequence boundaries are locally diachronous (see parasequence 6/7 boundary in Figs. 3 and
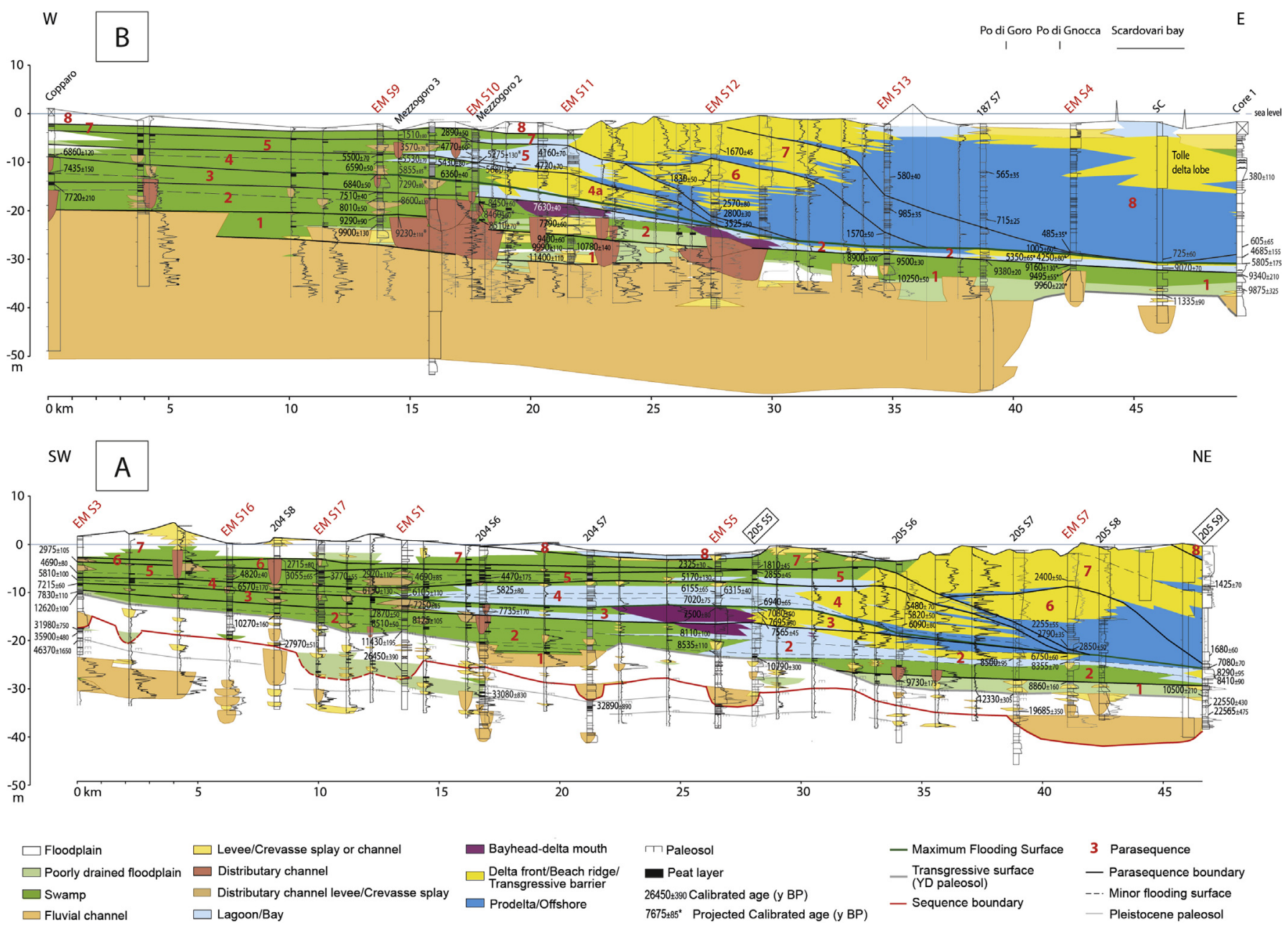

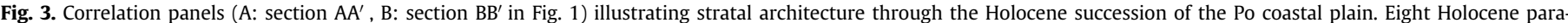

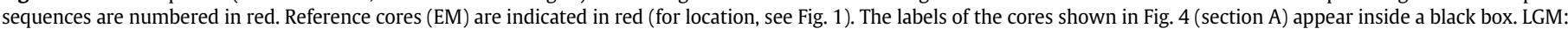
Last Glacial Maximum, YD: Younger Dryas. (For interpretation of the references to colour in this figure legend, the reader is referred to the web version of this article.) 
6). Stacking patterns may locally appear as degradational, because of the transect chosen relative to transport direction (e.g. parasequence 6 in Fig. 3). Delta front (foreset) and prodelta (bottomset) deposits are the most abundant facies, and each parasequence represents a phase of delta or shoreface progradation separated by short lived, mud prone transgressive incursions (clinoforms of Hampson et al., 2008). In a 2 D view (Fig. 3), clinoforms are mainly seen in near downdip sections (parasequences 6 and 7). Conversely, nearly horizontal bedding planes indicate sediment delivery perpendicular to the stratigraphic panel (see parasequence 8 in Fig. 3A). Farther inland, delta plain (swamp) deposits on the delta topset exhibit distinctive aggradational stacking patterns (Fig. 3).

Fossil data on meiofauna and mollusks contributed significantly to the identification and lateral tracing of parasequence boundaries and, more in general, of flooding surfaces (Fig. 4), especially where their distinction on a lithological basis is difficult. In freshwater to brackish deposits, parasequence boundaries are marked by changes in salinity or in the degree of confinement (Fig. 4a). In coastal to shallow marine deposits, flooding surfaces are localized at sharp lithofacies changes associated with abrupt deepening, from coastal/delta front sands to offshore/prodelta muds (Fig. 4b). The increase in water depth associated with flooding surfaces and parasequence boundaries can be estimated using quantitative bathymetric models based on mollusk assemblages (Wittmer et al., 2014 Fig. 4b). As an example, in the downdip sector of the southern transect (core 205 S9 in Fig. 3A), the paleodepth offset across the flooding surface at $10 \mathrm{~m}$ core depth (Fig. 4b) was estimated to be around $4.7 \mathrm{~m} \pm 2.8 \mathrm{~m}$ (see Scarponi and Angeletti, 2008).

A)

BENTHIC FORAMINIFERS

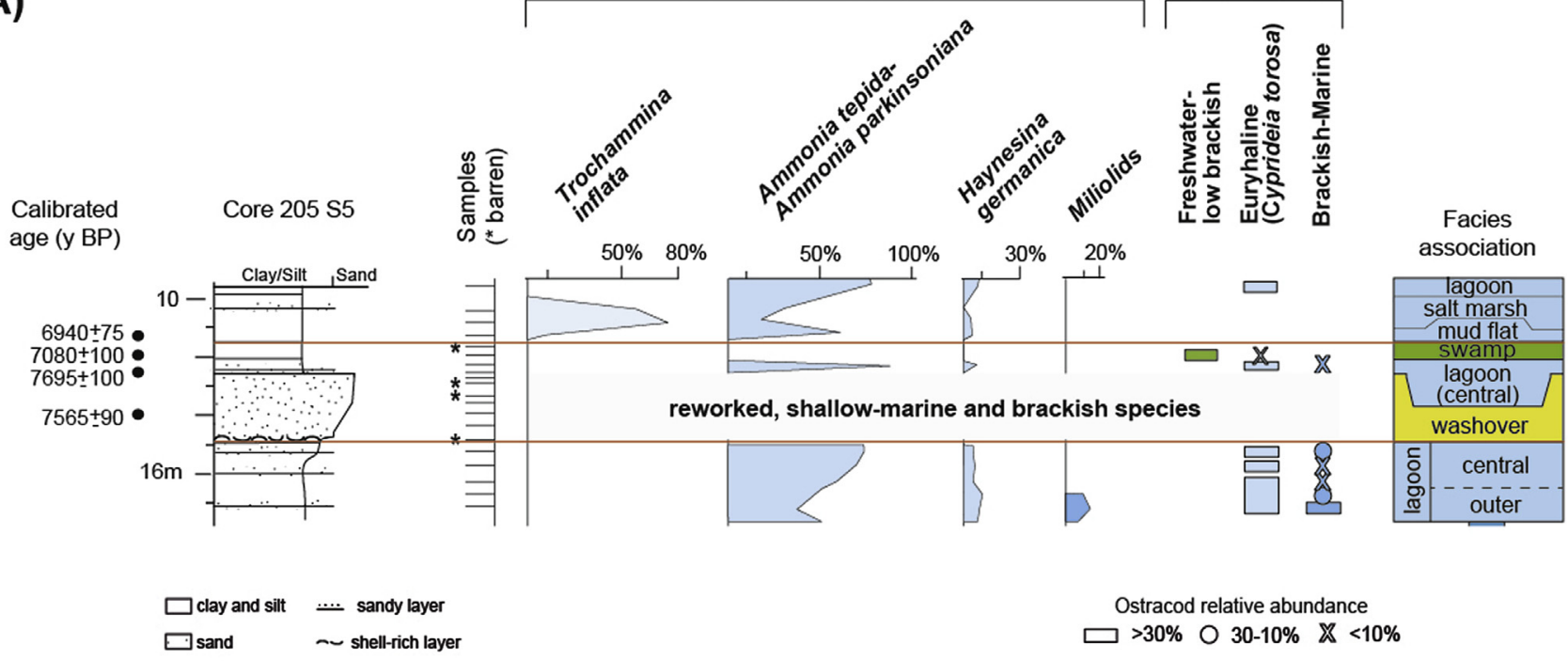

B)

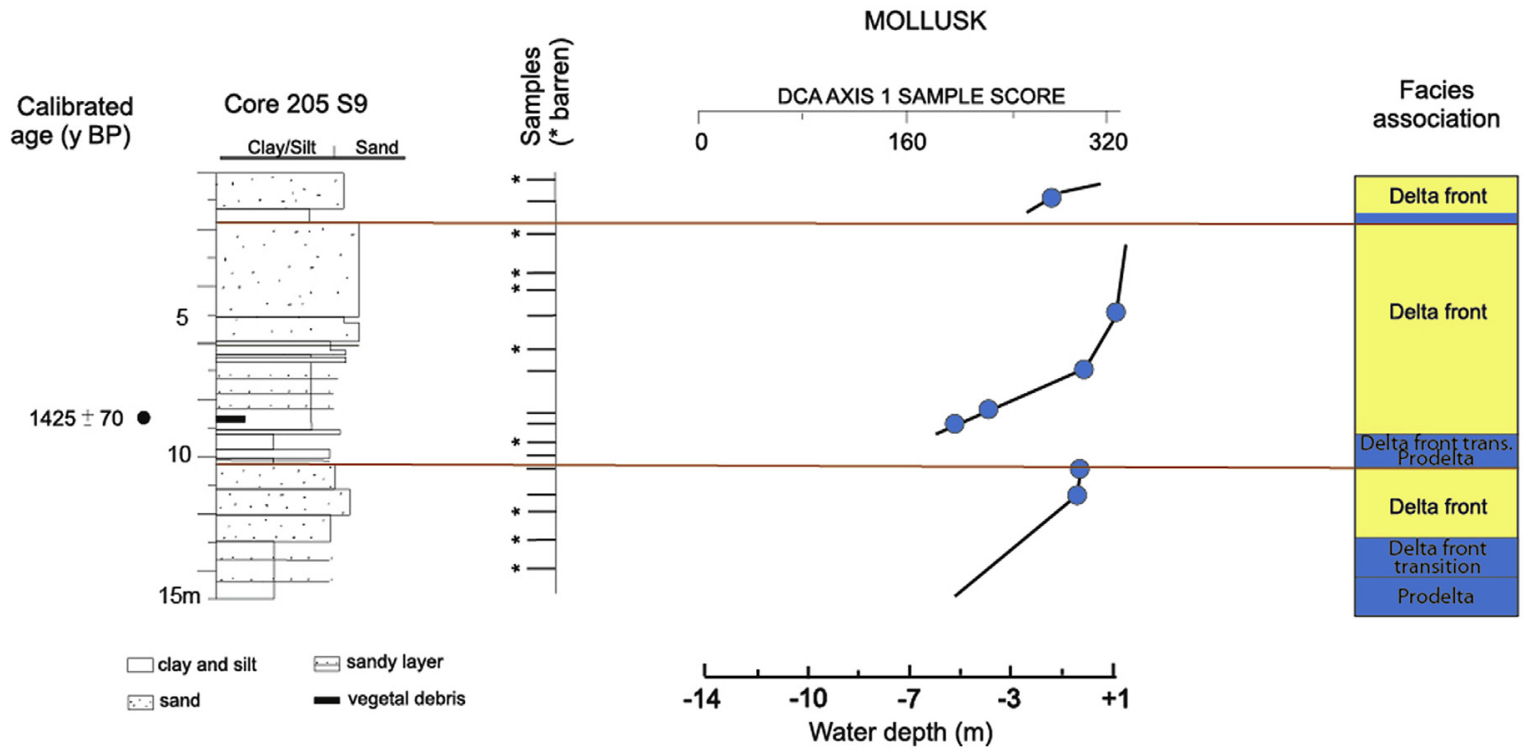

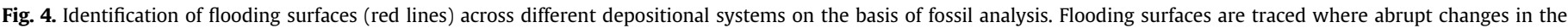

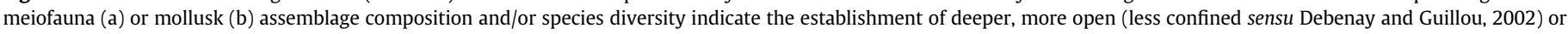

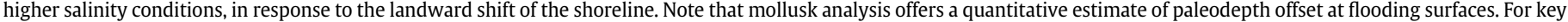

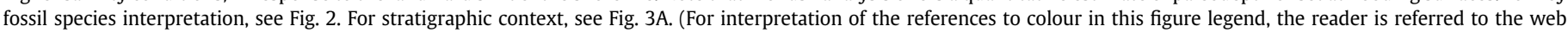
version of this article.) 


\section{Paleoenvironmental evolution}

Based on the relative proportion of facies associations, we reconstructed the dominant environments of deposition for each parasequence. This led to a comprehensive and detailed portrayal of paleoenvironmental evolution through the Holocene (Fig. 5).

During the YD, the shoreline was tens of km seawards from its present position, and the northern Adriatic was almost entirely subaerially exposed (Maselli et al., 2011). At that time, the Po River was a laterally migrating braided river system that flowed in NW SE direction across the study area (Fig. 5a). Lateral to the trunk river, a poorly mature paleosol (YD in Fig. 3) developed above very low elevation terraces (Amorosi et al., 2014a, 2016) (Fig. 5a). Three consecutive flooding surfaces (lower boundaries of parasequences 1-3) across estuarine, nearshore, and shallow marine deposits (Fig. 3 ) indicate the progressive drowning of the Po coastal plain. We interpret the spreading of freshwater wetlands over wide portions of the study area (Fig. 5b - parasequence 1 ) as a response of the Po coastal system to relative sea level rise. During this phase of 'initial flooding', the groundwater table was raised and promoted the vast accumulation and preservation of organic matter rich facies, which blanketed diachronously the transgressive surface
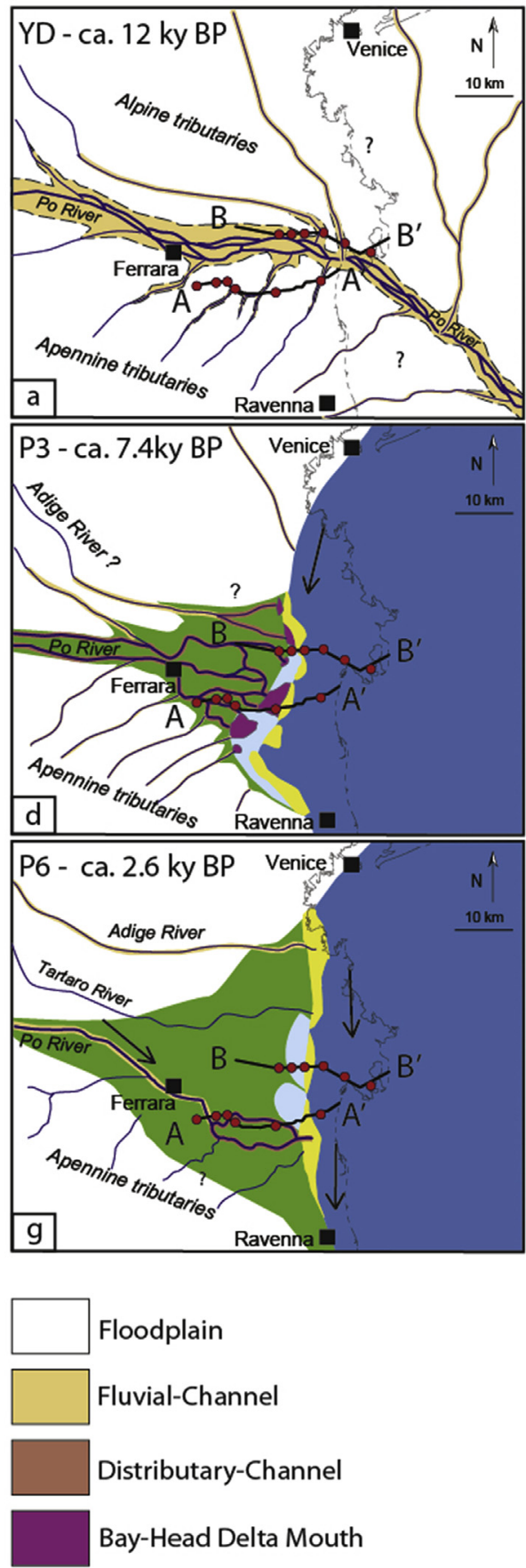

Floodplain

Fluvial-Channel

Distributary-Channel

Bay-Head Delta Mouth
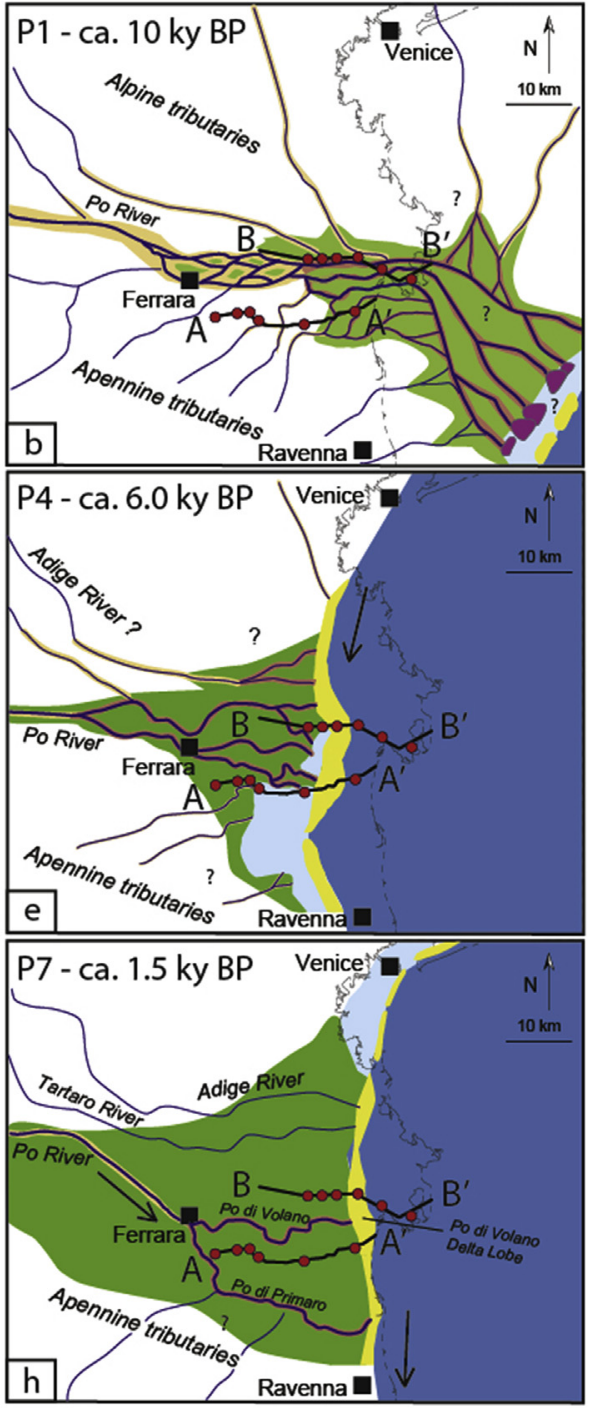

Inner-Estuary/Swamp/Delta Plain

Outer-Estuary/Lagoon

Transgressive barrier/

Beach-Ridge/Delta front

Offshore/Prodelta
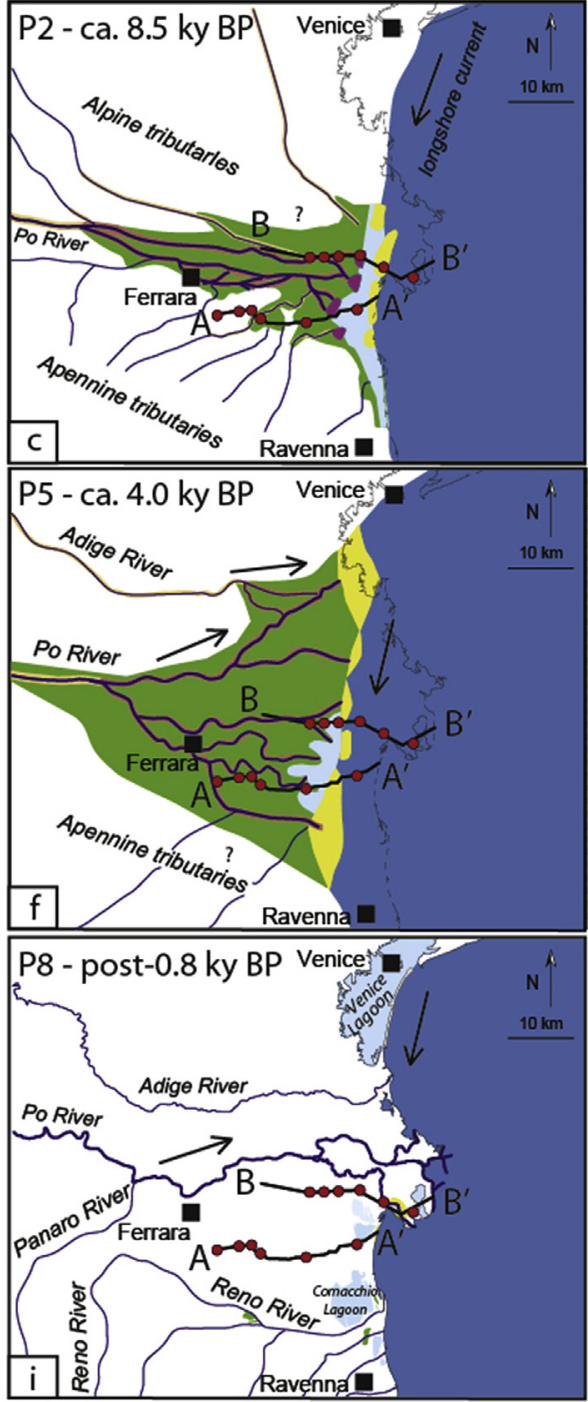

- Reference core

$\underline{\text { A } \quad \mathrm{A}^{\prime}}$ Cross section

Po River

Other rivers

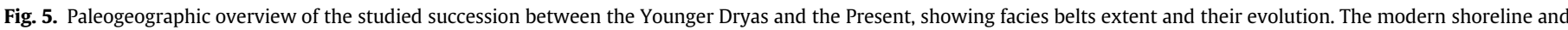
traces of cross-sections in Fig. 3 are present in each map for reference. YD: Younger Dryas, P: parasequence. 


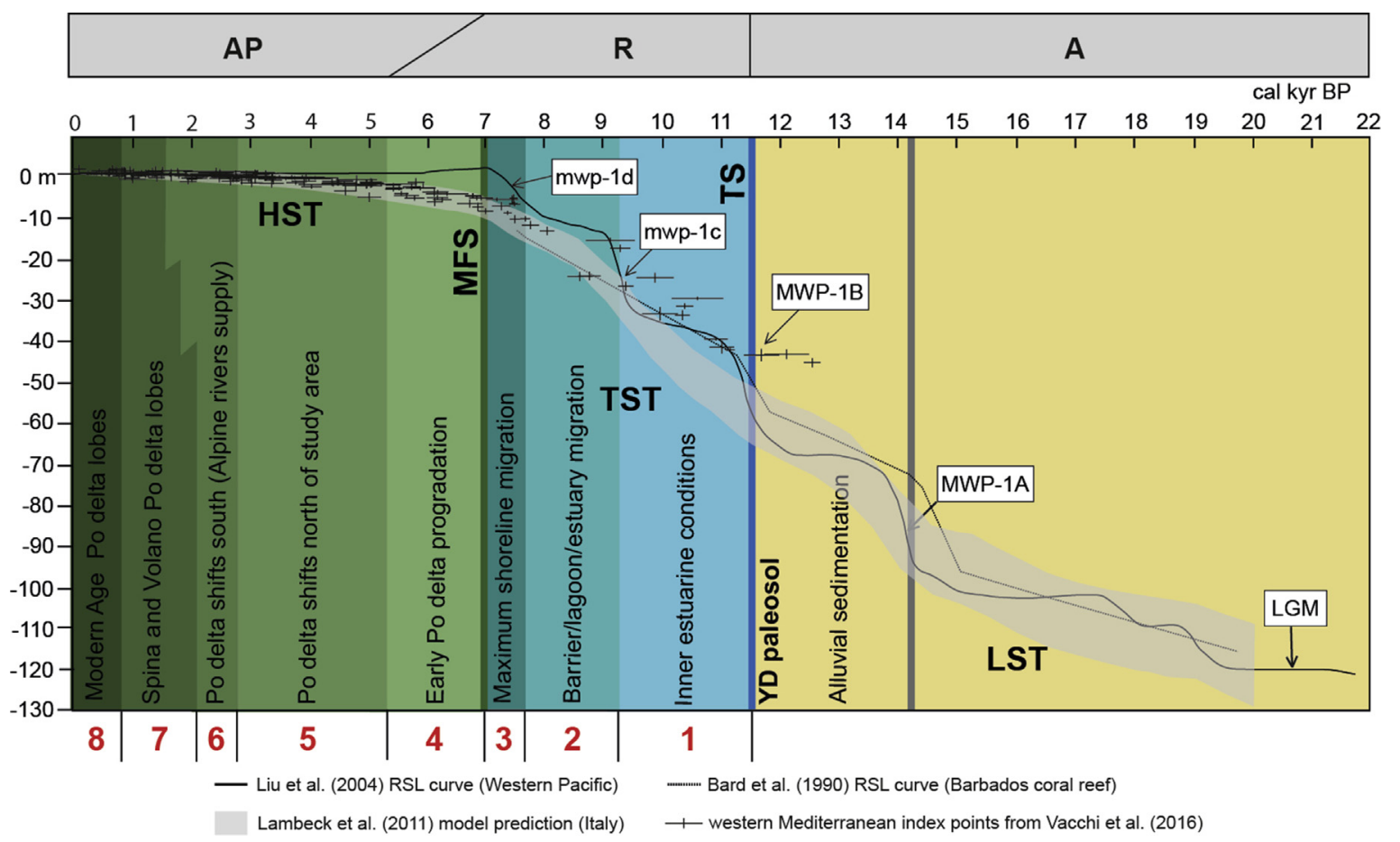

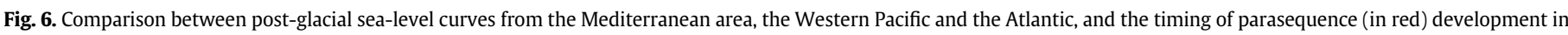

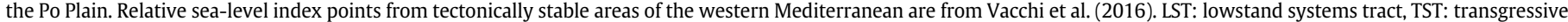

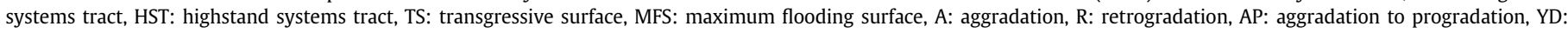

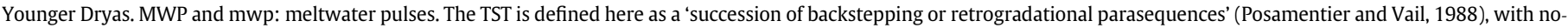

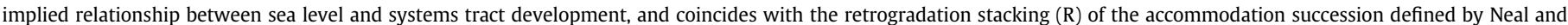
Abreu (2009). (For interpretation of the references to colour in this figure legend, the reader is referred to the web version of this article.)

(cf Bohacs and Suter, 1997) as a function of the pre existing topography (Rossi et al., 2011). The coastal plain was rapidly transformed into an inner estuary, which transitioned downdip to the Adriatic barrier island system (Trincardi et al., 1994; Correggiari et al., 2005; Amorosi et al., 2016).

Parasequence 2 records the rapid backstepping of the wave dominated estuary, and reveals its tripartite subdivision into (i) shoreline parallel barriers, (ii) a back barrier brackish zone, and (iii) a wide inner estuarine sector that hosted freshwater to low brackish sub environments, with associated bay head deltas at the fluvial mouths (Fig. 5c). Several closely spaced flooding sur faces, with small lateral extent, highlight the stepped trajectory of the transgressive shoreline on centennial time scales (dashed lines in Fig. 3A).

The maximum landward migration of the shoreline is dated to 7.7-7.0 cal ky BP (Fig. 5d - parasequence 3). At that time, the barrier became fixed (as revealed by the thicker transgressive sand body relative to parasequence 2 ), the estuary widened and the short lived YD terraces were flooded. Sediment trapping in the estuary was associated with sediment starvation on the shelf, as implied by several parasequences merging distally into an interval of condensed sedimentation, only a few dm thick (Fig. 3). Renewed bay head delta progradation took place at peak transgression, with partial filling of the lagoon (Fig. 5d).

Several coarsening upward and shallowing upward cycles of prodelta/delta front sediments (parasequences 4-8) indicate that after $7.0 \mathrm{cal} \mathrm{ky} \mathrm{BP}$, coastal progradation took place in the modern southern Po Plain (Fig. 3). The earlier deltaic system (7.0-5.2 cal ky BP parasequence 4) developed through delta lobe switching processes in a river dominated shoreline, probably under a general mechanism of compensational stacking (see Hampson, 2016). The locus of delta initiation was located in the area between the two stratigraphic panels, where a lobate delta accumulated in relatively shallow waters (Fig. 5e). While the Po River was building out its first delta system, a wide brackish zone developed behind the line of maximum landward migration of the shoreline (Figs. 5e and $3 \mathrm{~A}$ ). It can be plausibly argued that marine incursion took place to the south in response to dramatically reduced fluvial input at that location, following the abandonment of the formerly active bay head delta system (cf Rodriguez et al., 2010). When the Po River branch that flowed through Ferrara (Fig. 5d) became inactive, the brackish zone extended considerably in the southern part of the study area, probably enhanced by subsidence due to sediment compaction. This region likely experienced increasing tidal influence, especially away from areas of high fluvial input (Tanabe et al., 2015; Longhitano et al., 2016). A possible tidal influence is sug gested by the development of a widespread mud flat (see core EM S5 in Fig. 4a), with highly sinuous (tidal?) channels detected on the basis of satellite imagery (Sgavetti and Ferrari, 1988).

The spatially and temporally restricted advance of the early Po Delta system is attributed to river avulsion ( $\sim$ cal ky BP) that formed a new branch of the Po River in the north, close to the Venice region (Saline Cona branch of Piovan et al., 2012), whereas other distributary channels moved to the south (Fig. 5f). A brackish environment developed in the area delimited by sections $\mathrm{AA}^{\prime}$ and BB' (Fig. 5f). Modest to negligible volumes of sand were delivered during this interval of time to the adjacent shoreline, which remained temporarily starved of terrigenous sedimentation (parasequence 5 in Fig. 3).

The paleoenvironmental evolution between 2.8 and 0.8 cal ky BP (parasequences 6-7) matches well with geomorphic features described at length by Ciabatti (1967), Sgavetti and Ferrari (1988), Bondesan et al. (1995), Correggiari et al. (2005), and Stefani and Vincenzi (2005), who documented the widespread development 
of arcuate deltas with straight coastline morphology, in response to substantial sediment reworking by waves. Multiple episodes of river avulsion during progradation resulted in deposition of a nearshore sand body that is continuous along depositional strike (Hampson and Howell, 2005). A dominant sediment supply from the Adige River in the north, with sediment redistribution to the south by the longshore drift, is reinforced by the change in prove nance, recorded in beach sands of parasequence 6 , towards an Alpine composition (Fig. 5g-Marchesini et al., 2000). Active sedi ment delivery by the Po River was re established diachronously in the study area, between around 2 cal ky BP, with the growth of the Po di Spina and Po di Volano delta lobes (Parasequence 7 Fig. 5h), Finally, parasequence 8 marks the historical (1152 AD) Po River avulsion in Ficarolo, NW of Ferrara, which shifted the Po River to wards its present, northern position (Fig. 5i). During this period, the delta plain was intermittently exposed and flooded, as documented by the development of parasequences locally bounded by laterally continuous peat layers (Fig. 3A).

\section{Sediment accumulation rates}

With the thickness of sedimentary units and the age of accumulation available on a regional scale, we estimated sediment accumulation rates in the study area, and their change through space and time. Landwards of the shoreline (behind the limit of maximum shoreline ingression), relatively high accumulation rates (5-6 $\mathrm{mm} / \mathrm{y})$ are apparent for the transgressive parasequence set 1-3 (estimates from core EM S5 - Fig. 3A). Accumulation rates decrease in the lower HST $(2.5-3 \mathrm{~mm} / \mathrm{y}$ for parasequences $4-5)$, and attain minimal values $(1.0-1.5 \mathrm{~mm} / \mathrm{y}$ ) in the upper HST (parasequences 6-8). Basinward of the shoreline, the system records an opposite tendency: although aggradation rates are high in back barrier position ( $>4 \mathrm{~mm} / \mathrm{y}$ for transgressive parasequence 1 , from core EM S13 - Fig. 3B), strong condensation is recorded around the MFS $(<0.2 \mathrm{~mm} / \mathrm{y})$, and high sedimentation rates (up to $\sim 70 \mathrm{~mm} / \mathrm{y}$ ) are observed in the upper HST (Scarponi et al., 2013; Bruno et al., 2016).

The high rates of sediment accumulation recorded by the back barrier deposits (lower TST) are interpreted to reflect a generation of accommodation in the coastal plain, as a result of relative sea level rise. Progressively decreasing sedimentation rates followed sea level stabilization, suggesting that the coastal system was rapidly prograding basinwards. The coastal plain was transitioning from a sediment storage region to one of sediment bypass, which accounts for the condensed character of the upper TST/lower HST in seaward position.

High sediment storage in the coastal plain during transgression also implies a low potential to deliver sand to the deepwater slope and basin floor (Uroza and Steel, 2008). This trend has been recently documented by quantitative assessments of sediment budgets in the Po Plain Adriatic system (Amorosi et al., 2016), where sediment delivery to the deepest parts of the basin at sea level lowstand times has been estimated to be 20-25 times larger than during the following eustatic rise.

\section{Influence of sea-level change on Holocene parasequence architecture}

Linking the Holocene stratigraphic architecture of the Po coastal plain to local and global curves of post glacial sea level change available in literature reveals the possible influence of changing sea level on the generation of millennial scale parasequences.

During the Last Glacial Maximum (LGM), sea level stood 120-130 m lower than today (Fairbanks, 1989; Bard et al., 1996; Yokoyama et al., 2000). The post LGM global sea level rise was punctuated by high frequency oscillations, with short phases of sea level deceleration. A comprehensive, post LGM sea level curve has been reported by Liu et al. (2004) from the Western Pacific area. Consistent with previous reconstructions from coral reef cores (Fairbanks, 1989; Bard et al., 1990, 1996; Chappell and Polach, 1991), this curve shows a typical stepwise trend, characterized by four short lived phases of rapid eustatic rise, corresponding to large inputs of freshwater (meltwater pulses MWP and mwp) triggered by the melting of large continental ice sheets, separated by longer periods of slow transgression or stillstand (Fig. 6).

Although sea level started to rise around $19 \mathrm{cal} \mathrm{ky} \mathrm{BP}$, the first phase of rapid eustatic rise (MWP 1A) took place around $14 \mathrm{cal} \mathrm{ky}$ BP (Fairbanks, 1989; Bard et al., 1990, 1996; Blanchon and Shaw, 1995). Sea level rise slowed down during the YD, as recorded at several far field sites (Bard et al., 1996, 2010), before accelerating again at the beginning of the Holocene (MWP 1B at 11.6-11.3 cal ky BP, Fairbanks, 1989 - see Fig. 6). An acceleration in sea level rise is recorded during the same interval of time also in the Mediterra nean (Lambeck et al., 2011; Vacchi et al., 2016 - Fig. 6). In the Po-Adriatic system, this phase triggered the inundation of the Younger Dryas alluvial plain, recorded by parasequence 1 .

Two additional, rapid phases of eustatic rise, though of lower magnitude, have been identified within the Holocene period (Liu et al., 2004), between 9.5 and 9.2 cal ky BP (mwp 1c) and 8.0-7.5 cal ky BP (mwp 1d - Fig. 6). Taking into account eustatic, isostatic and tectonic effects, Lambeck et al. (2011) reconstructed a distinctive acceleration in sea level rise for the Italian coasts between 10.0 and 8.7 cal ky BP (Fig. 6). Data from the Po coastal plain preserve evidence for two phases of generalized flooding, starting at $\sim 9.2$ cal ky BP (parasequence 2) and 7.7 cal ky BP (parasequence 3), respectively (see Figs. 3 and 6), which support the hypothesis of an allogenic control on Early Holocene sedimentation.

The possible supra regional influence of sea level change on the initiation of parasequences 2 and 3 is also corroborated by radio carbon data from several coastal systems worldwide. For instance, the transition from freshwater to brackish environments (parasequence 2), marking the phase in which the increase in accommodation due to sea level rise abruptly exceeded the peat production rate (Bohacs and Suter, 1997), has been dated to 9.2 calky BP from the Song Hong River (Hori et al., 2004), whereas it slightly post dates 9.3 cal ky BP in the Rhône delta (Amorosi et al., 2013a), 9.4 cal ky BP in the Pearl River (Zong et al., 2009), and 9.6 cal ky BP in the Tuscan coastal plain (Amorosi et al., 2013b). In their detailed study on the Tokyo lowland, Tanabe et al. (2015) report the alluvial/tidal flat transition from core GS KBH 1 to have occurred at 9.5 cal ky BP.

The age distribution between 8.0 and 7.5 cal ky BP of the maximum flooding surfaces identified in four Italian coastal plains facing both the Tyrrhenian Sea and the Adriatic Sea (Amorosi et al., 2012, 2013b; 2016; Breda et al., 2016), are in agreement with the age of parasequence 3 (Fig. 6). The complete melting of the former ice caps, around 8.0-7.5 cal ky BP (Pirazzoli, 2005), drove maximum marine ingression and sea level around its present po sition (mwp 1d - Fig. 6). Nearly stable sea level conditions were conducive to worldwide delta initiation (Stanley and Warne, 1994). Given the flattening of the eustatic curve after 7 cal ky BP (Fig. 6), we can rule out global sea level as the dominant controlling factor of highstand parasequence development.

Although we do not expect highstand parasequences to be realistically recognizable on a basin scale, we demonstrate here that they can be traced individually over areas $>300 \mathrm{~km}^{2}$ wide, transcending depositional system boundaries. As argued by Catuneanu and Zecchin (2013), the autogenic shifting of deltas is likely to impact depositional processes not only in the deltaic 
depositional system, but also significantly modifying sediment supply to the adjacent open shorelines. This implies that autogenic driven parasequences might be identifiable across large expanses of the coastal system, losing their readily recognizable character only when moving to different segments of the source to sink system, such as the alluvial realm (farther inland) or the shelf (basinwards).

\section{Conclusions}

The Holocene depositional history of the Po coastal plain was reconstructed through stratigraphic correlation of eight parasequences developed on millennial time scales. Individual parasequences were physically traced confidently across the entire study area through a stratigraphic framework, additionally constrained chronologically by 132 radiocarbon dates. Changes in water depth, salinity and confinement levels were estimated from biofacies analysis, using meiofauna and mollusks, which allowed us to trace parasequence boundaries for tens of $\mathrm{km}$ landwards of the coeval shorelines.

We assessed architectural styles and the impact of short term sea level fluctuations on systems tract configuration. Back stepping parasequences (1-3) display a consistent and predictable pattern of transgressive deposits that records the transformation of the coastal plain into a wave dominated estuary. The rapid land ward migration of the transgressive barrier complex and related facies belt is punctuated by a set of higher frequency (centennial scale) flooding surfaces. Conversely, highstand parasequences (4-8) exhibit a complex aggradational to progradational stacking pattern of deltaic and coastal deposits. Sedimentation rates reveal strong sediment volume partitioning, with considerable sediment storage in the coastal plain during transgression, followed by sediment by pass and coastal progradation during sea level highstand.

The detailed chronostratigraphic framework enabled us to discriminate between allogenic and autogenic processes that may have driven the observed changes in parasequence development and shoreline trajectory. Eustasy appears to be a dominant control on stratigraphic architecture of Early Holocene parasequences, as documented by the striking correlation between the ages of our flooding surfaces 1-3 and global/Mediterranean sea level fluctuations. Conversely, parasequence development in Middle to Late Holocene deposits appears to have been dominantly controlled by autogenic processes (channel avulsion and delta lobe switching) during the generalized phase of sea level stabilization.

This study enhances our knowledge about depositional controls and the stratigraphic response of coastal systems to short term (millennial scale) sea level fluctuations, providing fundamental insights into modelling and prediction of parasequence architecture from the rock record. Reconstructing the dominant environments of deposition over millennial time scales (i.e., individual parasequences) is likely to provide a much more robust and detailed mapping of the extent and thickness of sediment bodies than using systems tracts. In the study area, where sea level control on parasequence stacking patterns and shoreline trajectory is documented rather than inferred, we see that parasequences developed on similar spatial and temporal scales, irrespective of their allogenic or autogenic controlling mechanisms. Parasequences of allogenic origin can be traced basinwide. Parasequences governed by autogenic mechanisms can be traced over areas at least $300 \mathrm{~km}^{2}$ wide, across distinct depositional systems. Only at the basin scale, their bounding surfaces are likely to become poorly predictable. These observations suggest that similar patterns in ancient strata could be used to infer the relative influence of allogenic and autogenic controls.

\section{Acknowledgments}

This study was supported by ExxonMobil Upstream Research Company, Spring, TX, USA. We are indebted to the Editor, Sergio Longhitano for his helpful comments. We are very grateful to Marcello Tropeano and to an anonymous reviewer for appropriate and constructive suggestions.

\section{Appendix A. Supplementary data}

Supplementary data related to this article can be found at http:// dx.doi.org/10.1016/j.marpetgeo.2017.01.020.

\section{References}

Abreu, V., Neal, J.E., Bohacs, K.M., Kalbas, J.L. (Eds.), 2010. Sequence Stratigraphy of Siliciclastic Systems: the ExxonMobil Methodology; Atlas of Exercises. SEPM, Tulsa, Oklahoma, pp. 1226.

Amorosi, A., Milli, S., 2001. Late Quaternary depositional architecture of Po and Tevere river deltas (Italy) and worldwide comparison with coeval deltaic suc-cessions. Sediment. Geol. 144, 357 375. http://dx.doi.org/10.1016/ S0037-0738(01)00129-4.

Amorosi, A., Colalongo, M.L., Pasini, G., Preti, D., 1999. Sedimentary response to late Quaternary sea-level changes in the Romagna coastal plain (northern Italy). Sedimentology 46, 99 121. http://dx.doi.org/10.1046/j.1365-3091.1999.00205.x.

Amorosi, A., Centineo, M.C., Colalongo, M.L., Pasini, G., Sarti, G., 2003. Facies architecture and latest Pleistocene-Holocene depositional history of the Po delta (comacchio area, Italy). J. Geol. 111, 39 56. http://dx.doi.org/10.1086/344577.

Amorosi, A., Colalongo, M.L., Fiorini, F., Fusco, F., Pasini, G., Vaiani, S.C., Sarti, G., 2004. Palaeogeographic and palaeoclimatic evolution of the Po Plain from 150-ky core records. Glob. Planet. Change 40, 55 78. http:// dx.doi.org/10.1016/S0921-8181(03)00098-5.

Amorosi, A., Centineo, M.C., Colalongo, M.L., Fiorini, F., 2005. Millennial-scale depositional cycles from the Holocene of the Po plain, Italy. Mar. Geol. 222223

7 18. http://dx.doi.org/10.1016/j.margeo.2005.06.041.

Amorosi, A., Pavesi, M., Ricci Lucchi, M., Sarti, G., Piccin, A., 2008. Climatic signature of cyclic fluvial architecture from the Quaternary of the central Po Plain, Italy. Sediment. Geol. 209, 58 68. http://dx.doi.org/10.1016/j.sedgeo.2008.06.010.

Amorosi, A., Ricci Lucchi, M., Rossi, V., Sarti, G., 2009. Climate change signature of small-scale parasequences from Lateglacial Holocene transgressive deposits of the Arno valley fill. Palaeogeography, Palaeoclimatology. Palaeoecology 273, 142 152. http://dx.doi.org/10.1016/j.palaeo.2008.12.010.

Amorosi, A., Pacifico, A., Rossi, V., Ruberti, D., 2012. Late Quaternary incision and deposition in an active volcanic setting: the Volturno valley fill, southern Italy. Sediment. Geol. 282, 307320

Amorosi, A., Rossi, V., Vella, C., 2013a. Stepwise post-glacial transgression in

the Rhône Delta area as revealed by high-resolution core data. Palaeogeography, $\begin{array}{lllll}\text { Palaeoclimatology. } & \text { Palaeoecology } 374, & 314 & 326 . & \text { http:/ }\end{array}$ dx.doi.org/10.1016/j.palaeo.2013.02.005.

Amorosi, A., Rossi, V., Sarti, G., Mattei, R., 2013b. Coalescent valley fills from the late quaternary record of Tuscany (Italy). Quat. Int. 288, 129 138. http://dx.doi.org/ 10.1016/j.quaint.2011.10.015.

Amorosi, A., Bruno, L., Rossi, V., Severi, P., Hajdas, I., 2014a. Paleosol architecture of

a late Quaternary basin margin sequence and its implications for highresolution, non-marine sequence stratigraphy. Glob. Planet. Change 112, 12 25. http://dx.doi.org/10.1016/j.gloplacha.2013.10.007.

Amorosi, A., Rossi, V., Scarponi, D., Vaiani, S.C., Ghosh, A., 2014b. Biosedimentary record of postglacial coastal dynamics: high-resolution sequence stratigraphy from the nortern Tuscan coast (Italy). Boreas 43, 939954.

Amorosi, A., Maselli, V., Trincardi, F., 2016. Onshore to offshore anatomy of a late Quaternary source-to-sink system (Po Plain-Adriatic Sea, Italy). Earth-Science Rev. 153, 212 237. http://dx.doi.org/10.1016/j.earscirev.2015.10.010.

Special Paper. In: Anderson, J.B., Rodriguez, A.B. (Eds.), 2008. Response of Gulf Coast Estuaries to Sea-level Rise and Climate Change, Geological Society of America, vol. 443, pp. 1146.

Arnott, R.W.C., 1995. The parasequence definition are transgressive deposits inadequately addressed? J. Sediment. Res. 65, 16.

Bard, E., Hamelin, B., Fairbanks, R.G., Zindler, A., 1990. Calibration of the ${ }^{14} \mathrm{C}$ timescale over the past 30,000 years using mass spectrometric $U$ Th ages from Barbados corals. Nature 345, 405410.

Bard, E., Hamelin, B., Arnold, M., Montaggioni, L., Cabioch, G., Faure, G., Rougerie, F., 1996. Deglacial sea-level record from Tahiti corals and the timing of global meltwater discharge. Nature 382, $241 \quad 244 . \quad$ http:/l dx.doi.org/10.1038/382241a0.

Bard, E., Hamelin, B., Delanghe-Sabatier, D., 2010. Deglacial meltwater pulse 1B and Younger Dryas sea levels revisited with boreholes in Tahiti. Science

327, 12351237 doi:101126/science.1180557.

Blanchon, P., Shaw, J., 1995. Reef drowning during the last deglaciation: evidence for catastrophic sea-level rise and ice-sheet collapse. Geology 23, 48. http://dx.doi.org/10.1130/0091-7613(1995)023. <0004:RDDTLD>2.3.CO;2. 
Blum, M.D., Tornqvist, T.E., 2000. Fluvial response to climate and sea level change: a review and look forward. Sedimentology 47, 2 48. http://dx.doi.org/10.1046/ j.1365-3091.2000.00008.x

Blum, M.D., Martin, J., Milliken, K., Garvin, M., 2013. Paleovalley systems: insights from Quaternary analogs and experiments. Earth Sci. Rev. 116, 128169. http://dx.doi.org/10.1016/j.earscirev.2012.09.003.

Boccaletti, M., Corti, G., Martelli, L., 2011. Recent and active tectonics of the external zone of the Northern Apennines (Italy). Int. J. Earth Sci. 100, 1331 1348. http:// dx.doi.org/10.1007/s00531-010-0545-y.

Bohacs, K., Suter, J., 1997. Sequence stratigraphic distribution of coaly rocks: fundamental controls and paralic examples. AAPG Bull. 81,1612 1639. Bondesan, M., Favero, V., Vinals, M.J., 1995. New evidence on the evolution of the Po-Delta coastal plain during the Holocene. Quat. Int. 29 30, 105 110. http:// dx.doi.org/10.1016/1040-6182(95)00012-8.

Boyd, R., Dalrymple, R., Zaitlin, B.A., 1992. Classification of clastic coastal depositional environments. Sediment. Geol. 80, 139 150. http://

dx.doi.org/10.1016/ 0037-0738(92)90037-R.

Breda, A., Amorosi, A., Rossi, V., Fusco, F., 2016. Late-glacial to Holocene depositional architecture of the Ombrone paleovalley system (Southern Tuscany, Italy): sealevel, climate and local control in valley-fill variability. Sedimentology 63, 1124 1148.http://dx.doi.org/10.1111/sed.12253.

Breman, E., 1975. The Distribution of Ostracodes in the Bottom Sediments of the Adriatic Sea. Ph.D thesis. Vrije Universiteit, Amsterdam.

Bruno, L., Amorosi, A., Severi, P., Costagli, B., 2016. Late Quaternary aggradation rates and stratigraphic architecture of the southern Po Plain, Italy. Basin Res. http://dx.doi.org/10.1111/bre.12174.

Burrato, P., Ciucci, F., Valensise, G., 2003. An inventory of river anomalies in the Po Plain, Northern Italy: evidence for active blind thrust faulting. Ann. Geophys. 46,865882 .

Campo, B., Amorosi, A., Vaiani, S.C., 2017. Sequence stratigraphy and late Quaternary paleoenvironmental evolution of the Northern Adriatic coastal plain (Italy). Palaeogeography, Palaoclimatology. Palaeoecology 466, 265278.

Cattaneo, A., Steel, R.J., 2003. Transgressive deposits: a review of their variability. Earth-Science Rev, 62, 187 228, http://dx.doi.org/10.1016/

S0012-8252(02) 00134-4

Catuneanu, O., Zecchin, M., 2013. High-resolution sequence stratigraphy of clastic shelves II: controls on sequence development. Mar. Petroleum Geol. 39, 2638. http://dx.doi.org/10.1016/j.marpetgeo.2012.08.010.

Chappel, J., Polach, H., 1991. Post-glacial sea-level rise from a coral record at Houn Peninsula, Papua New Guinea. Nature 349, 147 149. http://

dx.doi.org/10.1038/349147a0.

Ciabatti, M., 1967. Ricerche sull'evoluzione del Delta Padano. G. Geol. 34, 381406

Correggiari, A., Cattaneo, A., Trincardi, F., 2005. The modern Po Delta system: lobe switching and asymmetric prodelta growth. Mar. Geol. 222 223, 49 74. http:// dx.doi.org/10.1016/j.margeo.2005.06.039.

Curray, J.R., Moore, D.G., 1964. Pleistocene deltaic progradation of continental terrace, Costa de Nayarit, Mexico. In: AAPG Memoir, Marine Geology of the Gulf of California, pp. 193215.

Debenay, J.-P., Guillou, J.-J., 2002. Ecological transitions indicated by foraminiferal assemblages in paralic environments. Estuaries 25, 11071120 http://dx.doi.org/10.1007/BF02692208.

Demarest II, J.M., Kraft, J.C., 1987. Stratigraphic record of Quaternary sea levels: implications for more ancient strata. SEPM Special Publication. In: Nummedal, D., Piikey, O.H., Howard, J.D. (Eds.), Sea-level Fluctuations and Coastal Evolution, vol. 41, pp. 223239.

Fairbanks, R.G., 1989. A 17,000-year glacio-eustatic sea level record: influence of glacial melting rates on the Younger Dryas event and deep-ocean circulation.

Nature 342, 637642

Frazier, D.E., 1974. Depositional-episodes: their relationship to the quaternary stratigraphic framework in the northwestern portion of the Gulf basin. Bureau of economic geology, the University of Texas at Austin. Geol. Circ. 74, 128.

Hampson, G.J., Howell, J.A., 2005. Sedimentologic and geomorphic characterization of ancient wave-dominated deltaic shorelines: upper cretaceous blackhawk formation, book cliffs, Utah, U.S.A. SEPM Special Pubblication. In: Giosan, L., Bhattacharya, J.P. (Eds.), River Deltas Concepts, Models, and Examples, vol. 83, pp. 133154.

Hampson, G.J., Rodriguez, A.B., Storms, J.E.A., Johnson, H.D., Meyer, C.T., 2008. Geomorphology and high-resolution stratigraphy of progradational wavedominated shoreline deposits: impact on reservoir-scale facies architecture. SEPM Special Publication. In: Hampson, G.J., Steel, R.J., Burgess, P.M., Dalrymple, R.W. (Eds.), Recent Advances in Models of Siliciclastic ShallowMarine Stratigraphy, vol. 90, pp. 117142.

Hampson, G.J., 2016. Towards a sequence stratigraphic solution set for autogenic processes and allogenic controls: upper Cretaceous strata, Book Cliffs, Utah, USA. J. Geol. Soc. http://dx.doi.org/10.1144/jgs2015-136.

Hijma, M.P., Cohen, K.M., 2011. Holocene transgression of the Rhine river mouth area, The Netherlands/Southern North Sea: Palaeogeography and sequence stratigraphy. Sedimentology 58, 1453 1485. http://dx.doi.org/10.1111/ j.1365-3091.2010.01222x

Hori, K., Saito, Y., 2007. An early Holocene sea-level jump and delta initiation.

Geophys. Res. Lett. 34 http://dx.doi.org/10.1029/2007GL031029.

Hori, K., Saito, Y., Zhao, Q., Wang, P., 2002. Evolution of the coastal

depositional

systems of the Changjiang (Yangtze) River in response to late

Pleistocene-Holocene sea-level changes. J. Sediment. Res. 72, 884897.

Hori, K., Tanabe, S., Saito, Y., Haruyama, S., Nguyen, V., Kitamura, A., 2004

Delta initiation and Holocene sea-level change: example from the Song Hong (Red River) delta. Vietnam. Sediment. Geol. 164, 237249. http:// dx.doi.org/10.1016/j.sedgeo.2003.10.008.

Huntley, J.W., Scarponi, D., 2012. Evolutionary and ecological implications of trematode parasitism of modern and fossil northern Adriatic bivalvs. Paleobiology 38, 40 51. http://dx.doi.org/10.1017/S0094837300000397.

Huntley, J.W., Scarponi, D., 2015. Geographic variation of parasitic and predatory traces on mollusks in the northern Adriatic Sea, Italy: implications for the stratigraphic paleobiology of biotic interactions. Paleobiology 41, 134 153. http://dx.doi.org/10.1017/pab2014.9.

Jorissen, F.J., 1988. Benthic foraminifera from the Adriatic sea: principles of phenotypic variation. Utrecht Micropaleontol. Bull. 37, 174.

Kowalewski, M., Wittmer, J.M., Dexter, T.A., Amorosi, A., Scarponi, D., 2015. Differential response of marine communities to natural and anthropogenic changes. Proceedings of the Royal Society of London B 282, doi:10.1098/rspb.2014.2990.

Lambeck, K., Antonioli, F., Anzidei, M., Ferranti, L., Leoni, G., Scicchitano, G. Silenzi, S., 2011. Sea level change along the Italian coast during the Holocene and projections for the future. Quat. Int. 232, 250 257. http://dx.doi.org/ 10.1016/j.quaint.2010.04.026.

Leorri, E., Cearreta, A., 2004. Holocene environmental development of the Bilbao estuary, northern Spain: sequence stratigraphy and foraminiferal interpretation. Mar. Micropaleontol. 51, 7594. http://dx.doi.org/10.1016/ marmicro.2003.08.003.

Leorri, E., Martin, R., McLaughlin, P., 2006. Holocene environmental and parasequence development of the St. Jones Estuary, Delaware (USA): foraminifera proxies of natural climatic and anthropogenic change. Palaeogeography, Palaeoclimatology. Palaeoecology 241, 590 607. http://dx.doi.org/10.1016/ j.palaeo.2006.04.011.

Liu, J.P., Milliman, J.D., Gao, S., Cheng, P., 2004. Holocene development of the yellow River's subaqueous delta, north yellow sea. Mar. Geol. 209, 45 67. http:// dx.doi.org/10.1016/j.margeo.2004.06.009.

Longhitano, S.G., Della Luna, R., Milone, A.L., Cilumbriello, A., Caffau, M., Spilotro, G., 2016. The 20,000-years-long sedimentary record of the Lesina coastal system (southern Italy): from alluvial, to tidal, to wave process regime change. Holocene 26, 678698 .

Lowrie, A., Hamiter, R., 1995. Fifth and sixth order eustatic events during Holocene fourth order) highstand influencing Mississippi delta-lobe switching. J. Coast.

Res. Special Issue 17,225229.

Marchesini, L., Amorosi, A., Cibin, U., Zuffa, G.G., Spadafora, E., Preti, D., 2000. Sand composition and sedimentary evolution of a Late Quaternary depositional sequence, northwestern Adriatic Coast, Italy. J. Sediment. Res. 70, 829838 . http://dx.doi.org/10.1306/2DC4093B-0E47-11D7-8643000102C1865D.

Maselli, V., Hutton, E.W., Kettner, A.J., Syvitski, J.P.M., Trincardi, F., 2011. High-frequency sea level and sediment supply fluctuations during Termination I: an integrated sequence-stratigraphy and modeling approach from the Adriatic Sea (Central Mediterranean). Mar. Geol. 287, 54 70. http://dx.doi.org/10.1016/ j.margeo.2011.06.012

Mazzini, I., Rossi, V., Da Prato, S., Ruscito, V., 2017. Ostracods in archaeological sites along the Mediterranean coastlines: three case studies from the Italian peninsula. In: Williams, M., Hill, T., Boomer, I., Wilkinson, I.P. (Eds.), The Archaeological and Forensic Applications of Microfossils: a Deeper Understanding of Human History. Special Publication of the Micropalaeontological Society. Geological Society Publishing House, Bath (in press)

Milli, S., Mancini, M., Moscatelli, M., Stigliano, F., Marini, M., Cavinato, G.P., 2016. From river to shelf, anatomy of a high-frequency depositional sequence: the Late Pleistocene to Holocene Tiber depositional sequence. Sedimentology. http://dx.doi.org/10.1111/sed.12277.

Morton, R.A., Kindinger, J.L., Flocks, J.G., Stewart, L.B., 1999. Climatic-eustatic contro of Holocene nearshore parasequence development, southeastern Texas coast.

Gulf Coast Assoc. Geol. Soc. Trans. 49, 384395.

Muto, T., Steel, R.J., 1997. Principles of regression and transgression: the nature of the interplay between accommodation and sediment supply. J. Sediment. Res. 67, 9941000 .

Neal, J., Abreu, V., 2009. Sequence stratigraphy hierarchy and the accommodation succession method. Geology 37, 779 782. http://dx.doi.org/10.1130/G25722A.1.

Oomkens, E., 1970. Depositional sequences and sand distribution in the postglacial Rhone delta complex. SEPM Special Publication. In: Morgan, J.P. (Ed.), Deltaic Sedimentation, Modern and Ancient, vol. 15, pp. 198212.

Pieri, M., Groppi, G., 1981. Subsurface geological structure of the Po Plain, Italy. In: Pieri, M., Groppi, G. (Eds.), Progetto Finalizzato Geodinamica, vol. 414. C.N.R, Roma, pp. 123.

Piovan, S., Mozzi, P., Zecchin, M., 2012. The interplay between adjacent Adige and Po alluvial systems and deltas in the late Holocene (Northern Italy).

Géomorphologie 18, 427440.

Pirazzoli, P.A., 2005. A review of possible eustatic, isostatic, and tectonic contributions in eight late-Holocene relative sea-level histories from the Mediterranean area. Quat. Sci. Rev. 24, 1989 2001. http:// dx.doi.org/10.1016/j.quascirev.2004.06.026.

Posamentier, H.W., Vail, P.R., 1988. Eustatic controls on clastic deposition II sequence and systems tract models. SEPM Special Publication. In: Wilgus, C.K., Hastings, B.S., Kendall, C.G.S.C., Posamentier, H.W., Ross, C.A., Van Wagoner, J.C.(Eds.), Sea Level Changes: an Integrated Approach, vol. 42, pp. 125154.

Poulter, B., Feldman, R.L., Brinson, M.M., Horton, B.P., Orbach, M.K., Pearsall, S.H., Reyes, E., Riggs, S.R., Whitehead, J.C., 2009. Sea-level rise research and dialog in North Carolina: creating windows for policy change. Ocean Coast. Manag. 52, 
147 153. http://dx.doi.org/10.1016/j.ocecoaman.2008.09.010.

Ramsey, C.B., Lee, S., 2013. Recent and planned development of the program OxCal. Radiocarbon 55, 720 730. http://dx.doi.org/10.2458/azu_js_rc.55.16215.

Reimer, P.G., et al., 2013. IntCal13 and Marine13 radiocarbon age calibration curves 0-50,000 years cal BP. Radiocarbon 55, 1869 1887. http:// dx.doi.org/10.2458/azu_js_rc.55.16947.

Rizzini, A., 1974. Holocene sedimentary cycle and heavy mineral distribution, Romagna Marche coastal plain. Italy. Sediment. Geol. 11, 1737. http://dx.doi.org/10.1016/0037-0738(74)90003-7.

Rodriguez, A.B., Simms, A.R., Anderson, J.B., 2010. Bay-head deltas across the northern Gulf of Mexico back step in response to the 8.2 ka cooling event. Quat Sci. Rev. 29, 3983 3993. http://dx.doi.org/10.1016/j.quascirev.2010.10.004.

Rossi, V., Vaiani, S.C., 2008. Benthic foraminiferal evidence of sediment supply changes and fluvial drainage reorganization in Holocene deposits of the Po Delta, Italy. Mar. Micropaleontol. 69, 106 118. http://dx.doi.org/10.1016/ j.marmicro.2008.07.001.

Rossi, V., Amorosi, A., Sarti, G., Potenza, M., 2011. Influence of inherited topography on the Holocene sedimentary evolution of coastal systems: an example from

Arno coastal plain (Tuscany, Italy). Geomorphology 135, 117128.

Saito, Y., Katayama, H., Ikehara, K., Kato, Y., Matsumoto, E., Oguri, K., Oda, M., Yumoto, M., 1998. Transgressive and highstand systems tracts and post-glacial transgression, the East China sea. Sediment. Geol. 122, 217232.

Scarponi, D., Angeletti, L., 2008. Integration of palaeontological patterns in the sequence stratigraphy paradigm: a case study from Holocene deposits of the Po

Plain (Italy). GeoActa 7, 113.

Scarponi, D., Kowalewski, M., 2004. Stratigraphic paleoecology: bathymetric signatures and sequence overprint of mollusk associations from upper Quaternary sequences of the Po Plain, Italy. Geology 32, 989 992. http:// dx.doi.org/10.1130/G20808.1.

Scarponi, D., Kowalewski, M., 2007. Sequence stratigraphic anatomy of diversity patterns: late Quaternary benthic molluscs of the Po Plain, Italy. Palaios 22,

296 305. http://dx.doi.org/10.2110/palo.2005.p05-020r

Scarponi, D., Kaufman, D., Amorosi, A., Kowalewski, M., 2013. Sequence stratigraphy and the resolution of the fossil record. Geology 41, 239242.

Scarponi, D., Huntley, J.W., Capraro, L., Raffi, S., 2014. Stratigraphic palaeoecology of the Valle di Manche section (Crotone Basin, Italy): a candidate GSSP of the Middle Pleistocene. Palaeogeography, Palaeoclimatology. Palaeoecology 402, 30 43. http://dx.doi.org/10.1016/j.palaeo.2014.02.032.

Sgavetti, M., Ferrari, C., 1988. The use of TM data for the study of a modern deltaic depositional system. Int. J. Remote Sens. 9, 1613 1627. http://dx.doi.org/ $10.1080 / 01431168808954964$.

Somoza, L., Barnolas, A., Arasa, A., Maestro, A., Rees, J.G., Hernandez-Molina, F.J. 1998. Architectural stacking patterns of the Ebro delta controlled by Holocene high-frequency eustatic fluctuations, delta-lobe switching and subsidence processes. Sediment. Geol. 117, 11 32. http://dx.doi.org/10.1016/ S0037-0738(97)00121-8

Stanley, D.J., Warne, A.G., 1994. Worldwide initiation of Holocene marine deltas by deceleration of sea-level rise. Science 265, 228231.

Stefani, M., Vincenzi, S., 2005. The interplay of eustasy, climate and human activity in the late Quaternary depositional evolution and sedimentary architecture of the Po Delta system. Mar. Geol. 222 223, 1948. http:// dx.doi.org/10.1016/j.margeo.2005.06.029.

Storms, J.E.A., Weltje, G.J., Terra, G.J., Cattaneo, A., Trincardi, A., 2008. Coastal dynamics under conditions of rapid sea-level rise: late Pleistocene to Early Holocene evolution of barrier-lagoon systems on the northern Adriatic shelf (Italy). Quat. Sci. Rev. 27, 1107 1123. http://dx.doi.org/10.1016/ j.quascirev.2008.02.009

Suter, R.J., Berryhill Jr., H.L., Penland, S., 1987. Late Quaternary sea-level fluctuations and depositional sequences, southwest Louisiana continental shelf. SEPM Special Publication. In: Nummedal, D., Pilkey, O.H., Howard, J.D. (Eds.), Sea-level Fluctuation and Coastal Evolution, vol. 41, pp. 199219.

Tanabe, S., Hori, K., Saito, Y., Haruyama, S., Vu, V.P., Kitamura, A., 2003. Song Hong (Red River) delta evolution related to millennium-scale Holocene sea-level change. Quat. Sci. Rev. 22, 2345 2361. http://dx.doi.org/10.1016/ S0277-3791(03)00138-0.

Tanabe, S., Saito, Y., Lan Vu, Q., Hanebuth, T.J.J., Lan Ngo, Q., Kitamura, A., 2006. Holocene evolution of the Song Hong (Red River) delta system, northern Vietnam. Sediment. Geol. 187, 29 http://dx.doi.org/10.1016/ 61.j.sedgeo.2005.12.004

Tanabe, S., Nakanishi, T., Ishihara, Y., Nakashima, R., 2015. Millennial-scale stratigraphy of a tide-dominated incised valley during the last $14 \mathrm{kyr}$ : spatial and quantitative reconstruction in the Tokyo Lowland, central Japan. Sedimentology 62, 1837 1872. http://dx.doi.org/10.1111/sed.12204.

Tornqvist, T.E., Hijma, M.P., 2012. Links between early Holocene ice-sheet decay, sea-level rise and abrupt climate change. Nat. Geosci. 5, 601 606. http:// dx.doi.org/10.1038/ngeo1536.

Trincardi, F., Correggiari, A., Roveri, M., 1994. Late Quaternary transgressive record and deposition in a modern epicontinental shelf: the Adriatic semi-enclosed basin. Geo-Marine Lett. 14, 41 51. http://dx.doi.org/10.1007/BF01204470.

Uroza, C.A., Steel, R.J., 2008. A highstand shelf-margin delta system from the Eocene of West Spitsbergen, Norway. Sediment. Geol. 203, 229 245. http://dx.doi.org/ 10.1016/j.sedgeo.2007.12.003.

Vacchi, M., Marriner, N., Morhange, C., Spada, G., Fontana, A., Rovere, A., 2016. Multiproxy assessment of Holocene relative sea-level changes in the western Mediterranenan: sea-level variability and improvements in the definition of the isostatic signal. Earth-Science Rev. 155, 172 197.http://dx.doi.org/10.1016/ j.earscirev.2016.02.002.

Van der Zwaan, G.J., Jorissen, F.J., 1991. Special Publication. Biofacial Patterns in River-induced Shelf Anoxia, vol. 58. Geological Society, London, pp. 6582. http://dx.doi.org/10.1144/GSL.SP.1991.058.01.05

Van Wagoner, J.C., Posamentier, H.W., Mitchum, R.M., Vail, P.R., Sarg, J.F., Loutit,

T.S.,Hardenbol, J., 1988. An overview of the fundamentals of sequence stratigraphy and key definitions. SEPM Special Publication. In: Wilgus, C.K., Hastings, B.S. Kendall, C.G.St.C., Posamentier, H.W., Ross, C.A., Van Wagoner, J.C. (Eds.), Sealevel Changes: an Integrated Approach, vol. 42, pp. 3945.

Van Wagoner, J.C., Mitchum, R.M., Campion, K.M., Rahmanian, V.D., 1990. Siliciclastic Sequence Stratigraphy in Well Logs, Cores and Outcrops: Concepts for High Resolution Correlations of Time and Facies. American Association of Petroleum Geologists, Methods in Exploration 7, Tulsa, U.S.A, p. 55.

Wittmer, J.M., Dexter, T., Scarponi, D., Amorosi, A., Kowalewski, M., 2014. Quantitative bathymetric models for late Quaternary transgressive regressive cycles of thePo Plain, Italy. J. Geol. 122, 649 670. http://dx.doi.org/10.1086/677901. Yokoyama, Y., Lambeck, K., De Deckker, P., Johnston, P., Fifield, L.K., 2000. Timing of the last glacial maximum from observed sea-level minima. Nature 406, 713716 doi: 10.1038735021035.

Zecchin, M., Catuneanu, O., 2013. High-resolution sequence stratigraphy of clastic shelves I: units and bounding surfaces. Mar. Petroleum Geol. 39, 1 25. http:// dx.doi.org/10.1016/j.marpetgeo.2012.08.015

Zong, Y., Yim, W.W.-S., Yu, F., Huang, G., 2009. Late Quaternary environmental changes in the Pearl River mouth region, China. Quat. Int. 206, 35 45. http:// dx.doi.org/10.1016/j.quaint.2008.10.012. 